\title{
Controls on mesopelagic particle fluxes in the Sub-Antarctic and Polar Frontal Zones in the Southern Ocean south of Australia in summer-Perspectives from free-drifting sediment traps
}

\author{
Friederike Ebersbach ${ }^{\mathrm{a}, \mathrm{b}, *}$, Thomas W. Trull ${ }^{\mathrm{b}, \mathrm{c}, \mathrm{d}}$, Diana M. Davies ${ }^{\mathrm{b}}$, Stephen G. Bray ${ }^{\mathrm{b}}$ \\ a International Graduate School for Marine Science (GLOMAR), University of Bremen, Alfred Wegener Institute for Polar and Marine Research, Am Handelshafen 12, 27570 \\ Bremerhaven, Germany \\ ${ }^{\mathrm{b}}$ Antarctic Climate and Ecosystems Cooperative Research Centre, Hobart, Tasmania 7001, Australia

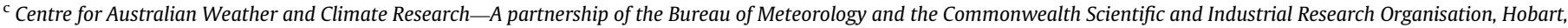 \\ Tasmania 7001, Australia \\ ${ }^{\mathrm{d}}$ Institute for Marine and Antarctic Studies, University of Tasmania, Hobart, Tasmania 7001, Australia
}

\section{A R T I C L E I N F O}

\section{Available online 30 May 2011}

Keywords:

Sinking particles

Export flux

Mesopelagic

Southern Ocean

SAZ

PFZ

\begin{abstract}
A B S T R A C T
The SAZ-Sense project examined ecosystem controls on Southern Ocean carbon export during austral summer (January-February 2007) at three locations: P1 in the low biomass Subantarctic Zone (SAZ) west of Tasmania, P3 in a region of elevated biomass in the SAZ east of Tasmania fuelled by enhanced iron supply, and P2 in High-Nutrient/Low Chlorophyll (HNLC) Polar Frontal Zone (PFZ) waters south of P1 and P3. Sinking particles were collected using (i) a cylindrical time-series (PPS3/3) trap for bulk geochemical fluxes, (ii) indented rotating sphere (IRS) traps operated as in-situ settling columns to determine the flux distribution across sinking-rate fractions, and (iii) cylindrical traps filled with polyacrylamide gels to obtain intact particles for image analysis.

Particulate organic carbon (POC) flux at $150 \mathrm{~m}$ (PPS3/3 trap) was highest at P1, lower at P2, and lowest at P3 (3.3 $\pm 1.8,2.1 \pm 0.9$, and $0.9 \pm 0.4 \mathrm{mmol} \mathrm{m}^{-2} \mathrm{~d}^{-1}$, respectively). Biogenic silica (BSi) flux was very low in the SAZ $\left(0.2 \pm 0.2\right.$ and $0.02 \pm 0.005 \mathrm{mmol} \mathrm{m}^{-2} \mathrm{~d}^{-1}$ at $\mathrm{P} 1$ and $\mathrm{P} 3$, respectively) and much higher in the PFZ $\left(2.3 \pm 0.5 \mathrm{mmol} \mathrm{m}^{-2} \mathrm{~d}^{-1}\right.$ at P2). Hence, the high biomass site P3 did not exhibit a correspondingly high flux of either POC or BSi. Separation of sinking-rate fractions with the IRS traps (at 170 and $320 \mathrm{~m}$ depth) was only successful at the PFZ site P2, where a relatively uniform distribution of flux was observed with $\sim 1 / 3$ of the POC sinking faster than $100 \mathrm{~m} \mathrm{~d}^{-1}$ and $1 / 3$ sinking slower than $10 \mathrm{~m} \mathrm{~d}^{-1}$.

Analysis of thousands of particles collected with the gel traps (at 140, 190, 240, and $290 \mathrm{~m}$ depth) enabled us to identify 5 different categories: fluff-aggregates (low-density porous or amorphous aggregates), faecal-aggregates (denser aggregates composed of different types of particles), cylindrical and ovoid faecal pellets, and isolated phyto-cells (chains and single cells). Faecal-aggregates dominated the flux at all sites, and were larger in size at P1 in comparison to P3. The PFZ site P2 differed strongly from both SAZ sites in having a much higher abundance of diatoms and relatively small-sized faecalaggregates. Overall, the particle images suggest that grazing was an important influence on vertical export at all three sites, with differences in the extents of large aggregate formation and direct diatom export further influencing the differences among the sites.
\end{abstract}

(c) 2011 Elsevier Ltd. All rights reserved.

\section{Introduction}

The downward transfer of particulate organic carbon within the sea by biological processes, known as the biological pump, had a strong influence in maintaining low pre-industrial atmospheric $\mathrm{CO}_{2}$

\footnotetext{
* Corresponding author at: International Graduate School for Marine Science (GLOMAR), University of Bremen, Alfred Wegener Institute for Polar and Marine Research, Am Handelshafen 12, 27570 Bremerhaven, Germany.

E-mail address: friederike.ebersbach@awi.de (F. Ebersbach).
}

levels (Volk and Hoffert, 1985). Its response to industrial $\mathrm{CO}_{2}$ emissions is uncertain, and is expected to be relatively moderate, but merits consideration in assessing the magnitude of emissions reductions required for stabilisation of atmospheric $\mathrm{CO}_{2}$ (Sarmiento and Le Quéré, 1996; Matear and Hirst, 1999; Falkowski et al., 2000). The overall strength of the biological pump can be thought of as consisting of three steps: (i) primary production of organic matter by photosynthesis, (ii) export of a fraction of this production from the euphotic zone as sinking particles, and (iii) attenuation of this sinking flux by mesopelagic processes that limit the depth to which it is 
transferred and thus the duration over which it remains isolated from the atmosphere. Each of these steps exhibits similar variance and thus has similar potential importance in the control of the pump efficiency (Boyd and Trull, 2007; Kwon et al., 2009), but the factors controlling these steps are still under debate (Boyd and Trull, 2007; Buesseler and Boyd, 2009).

Attempts to predict the organic carbon export flux from primary production or phytoplankton biomass accumulation have not been very successful, because primary and export production are often decoupled by other aspects of ecosystem structure (e.g. Bishop, 1989; Buesseler, 1991; Boyd and Newton, 1995, 1999; Buesseler and Boyd, 2009). Of particular interest is determining the conditions under which phytoplankton can be directly exported via physical flocculation and sinking, without passing through higher trophic levels that engender respiration losses of POC (Michaels and Silver, 1988; Alldredge and Jackson, 1995; Turner, 2002).

Globally distributed deep ocean sediment trap programs have revealed some of the factors that correlate with high POC flux, including the presence of ballast minerals (primarily autochthonous biogenic carbonates and silica, and secondarily allochthonous lithogenic particles) and the occurrence of strong seasonality (Lampitt and Antia, 1997; Armstrong et al., 2002; Francois et al., 2002; Klaas and Archer, 2002; Lutz et al., 2002, 2007). However the importance of minerals is less clear at mesopelagic depths, where POC dominates particle contents to a much greater degree, particle size, and porosity are strong influences on sinking rates (Alldredge and Gotschalk, 1988; Alldredge, 1998; Passow, 2004; Stemmann et al., 2004; De La Rocha and Passow, 2007), and where the vast majority of flux attenuation occurs (Martin et al., 1987; Buesseler et al., 2007a).

In this context of uncertainty regarding the controls on particle export and attenuation, particularly at mesopelagic depths, methods that directly examine the forms and compositions of sinking particles are useful. In this study, we used three different types of mesopelagic free-drifting sediment traps to determine (i) POC and mineral ballast fluxes, (ii) particle sinking rates, and (iii) particle sizes and shapes. These methods let us examine several currently debated aspects of the controls on POC flux, including the roles of phytoplankton flocs, zooplankton faecal pellets, ballast minerals, and particle aggregation processes.

\section{Material and methods}

\subsection{Study area}

The SAZ-Sense study took place in the Australian sector of the Southern Ocean and was carried out during midsummer (17 January-20 February 2007). Three process stations were studied in detail: P1 in the SAZ west of Tasmania, P3 in the SAZ east of Tasmania and P2 in the PFZ further south (Fig. 1), with a much more limited set of measurements carried out at intervening transect stations (see Bowie et al., 2011, for an overview). This paper focuses exclusively on the process stations, which were each occupied for approximately $6 \mathrm{~d}$. Sites P1 and P2 have been examined previously, including a process study (overview by Trull et al., 2001a), but this was the first process study at P3.

Site P1 is representative of a large proportion of the circumpolar SAZ, in terms of exhibiting iron limitation, seasonally low silicate levels, non-limiting nitrate and phosphate levels, low to moderate biomass throughout much of the year, and a mixed phytoplankton community that includes cyanobacteria, coccolithophores, small diatoms, and flagellates (Sedwick et al., 1999, 2008; Trull et al., 2001b; Rintoul and Trull, 2001; Wang et al., 2003). Site P2 is also representative of circumpolar conditions for the PFZ. It has very low dissolved iron levels, non-limiting

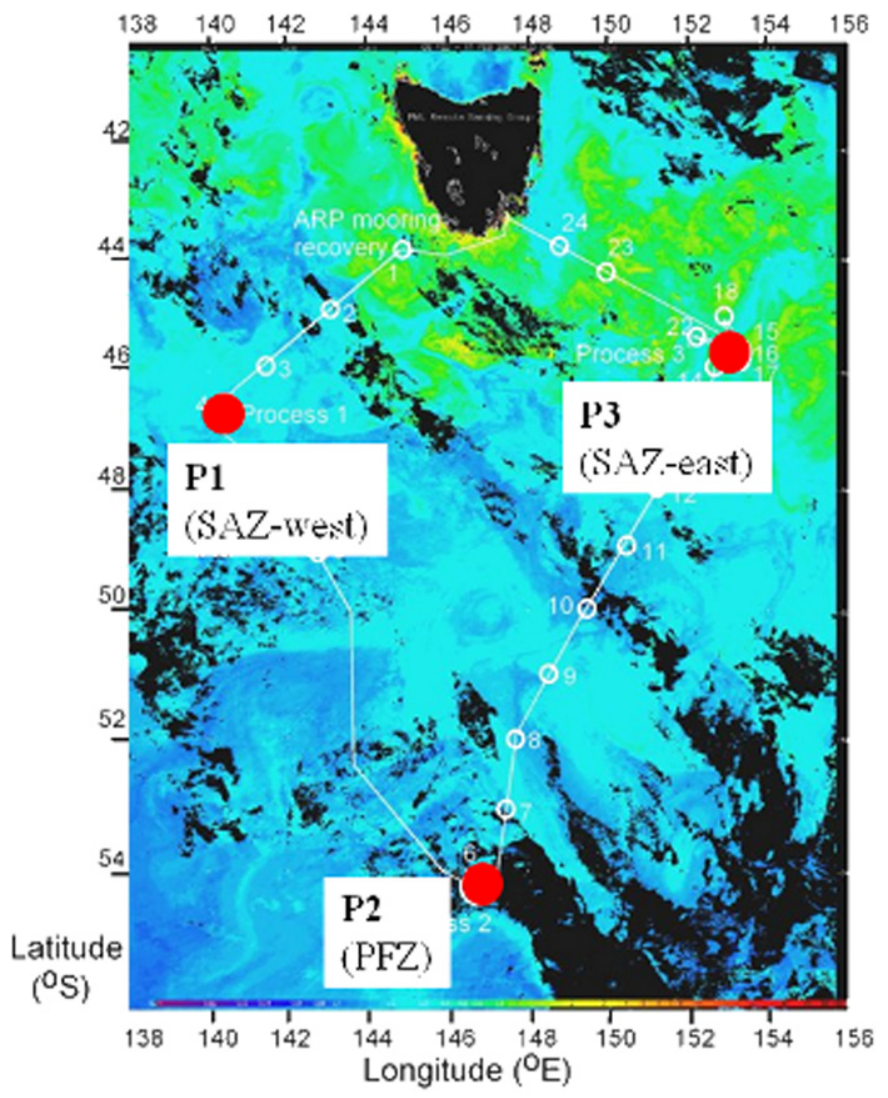

Fig. 1. Map of SAZ-Sense cruise track and station locations, superimposed on the surface chlorophyll distribution (MERIS ocean colour 1-km resolution composite image for 5-11 February 2007 courtesy of the Plymouth Marine Laboratory Remote Sensing Group; colour-scale is logarithmic from 0.01 to $60 \mu \mathrm{g} \mathrm{Chl} a \mathrm{~L}^{-1}$ ). Process Station P1, west of Tasmania in low-biomass Subantarctic waters was visited first, followed by P2 in the Polar Frontal Zone, and finally P3 in the high biomass SAZ east of Tasmania. Each Process Station was occupied for approximately $6 \mathrm{~d}$. The image corresponds to the time of the transect from P2 to P3.

macro-nutrient concentrations year-round, lower biomass with a pronounced summer maximum, and a phytoplankton community dominated by diatoms. These differences in surface water communities are also reflected in the composition of sinking particles reaching the deep sea, with carbonates dominating sediment trap collections at P1 and silica dominating P2 (Trull et al., 2001b).

Site P3 differs from the circumpolar conditions that prevail at P1 and P2, in that it receives inputs of southward flowing oligotrophic waters from eddies generated by the East Australian Current-an influence that has been increasing strongly in recent decades (Hill et al., 2008). Increased iron supply is observed in this region of the SAZ (Bowie et al., 2009), as are surface biomass levels as observed by satellite remote sensing (Mongin et al., 2011). Thus, this site offers the opportunity to observe the response of export to natural iron inputs to the Subantarctic Zone, which can be compared to other Southern Ocean natural iron fertilisation studies such as CROZEX (Pollard et al., 2007) and KEOPS (Blain et al., 2007).

In the absence of sustained observations, the main indication of the seasonal context of the SAZ-Sense study comes from satellite observations. Ocean colour observations show the development of seasonal blooms with biomass accumulation starting in December 2006 at P1 and P2, and in February 2007 at P3 (Mongin et al., 2011). Based on those satellite ocean colour observations, the bloom at P3 was still growing, while the peak at P1 was already over and at P2 the bloom was strongly declining. Prior to the cruise, surface Chl $a$ levels based on SeaWiFS images were highest at P3, 
somewhat lower at P1 and lowest at P2 $(\sim 0.4, \sim 0.3$, and $\sim 0.25 \mathrm{mg} \mathrm{m}^{-3}$, respectively; Mongin et al., 2011).

The SAZ-Sense ship-board observations provide further detail of the oceanographic conditions (for an overview, see Bowie et al., 2011), including the vertical water column structure and associated biomass distributions. P1 had the shallowest mixed layer ( $41 \pm 18 \mathrm{~m})$, P2 had the deepest mixed layer $(53 \pm 6 \mathrm{~m})$, and P3 was characterised by a deep mixed layer $(79 \pm 2 \mathrm{~m})$ and a secondary shallower stratification ( $16 \pm 2 \mathrm{~m}$ ) (Table 1$)$. The euphotic depth was shallowest at P3 (47 $\pm 13 \mathrm{~m})$, and at a comparable depth range at P1 and P2 (61 \pm 5 and $76 \pm 14 \mathrm{~m}$, respectively, Table 1$)$. During the study surface Chl $a$ and surface POC were highest at P3, followed by P1 and P2 (Table 1). In keeping with the mixed layer and euphotic zone depth variations, in the SAZ (P1 and P3) the biomass maxima were shallower than at P2 in the PFZ (Fig. 2, Table 1). This correlation of shallow mixed layers with high biomass concentrations led to roughly similar standing stocks of Chl $a$ and POC (integrated over depth) at all 3 sites (Table 1). Primary production estimated from tracer incubation experiments exhibited strong variability at site P1 and similar values to P3, with somewhat lower values at the PFZ

Table 1

Water column properties at the process stations.

\begin{tabular}{|c|c|c|c|c|c|c|c|c|c|}
\hline \multirow{2}{*}{$\begin{array}{l}\text { Site } \\
\text { i.d. }\end{array}$} & \multirow{2}{*}{$\begin{array}{l}\text { Mixed layer } \\
\text { depth }(\mathbf{m})\end{array}$} & \multirow{2}{*}{$\begin{array}{l}\text { Euphotic layer } \\
\text { depth }(\mathbf{m})\end{array}$} & \multirow{2}{*}{$\begin{array}{l}\text { Surface Chl a } \\
\left(\mu \mathrm{g} \mathrm{L}^{-1}\right)\end{array}$} & \multirow{2}{*}{$\begin{array}{l}\text { Integrated } \\
\text { Chl } a \\
(0-150 \mathrm{~m}) \\
\left(\mathrm{mg} \mathrm{m}^{-2}\right)\end{array}$} & \multirow{2}{*}{$\begin{array}{l}\text { Surface POC } \\
\left(\mathrm{mmolC} \mathbf{m}^{-2} \mathrm{~d}^{-1}\right)\end{array}$} & \multirow{2}{*}{$\begin{array}{l}\text { Integrated POC } \\
(0-100 \mathrm{~m}) \\
\left(\mathbf{m m o l C} \mathbf{m}^{-2} \mathbf{d}^{-1}\right)\end{array}$} & \multicolumn{2}{|l|}{ Primary production } & \multirow[b]{2}{*}{$\begin{array}{l}\text { NPP } \\
\left(\mathrm{mmolC} \mathrm{m}^{-2} \mathbf{d}^{-1}\right)\end{array}$} \\
\hline & & & & & & & $\begin{array}{l}\text { GPP } \\
\left(\mathrm{mmolC} \mathrm{m}^{-2} \mathrm{~d}^{-1}\right)\end{array}$ & f-Ratio & \\
\hline P1 & $41 \pm 18$ & $61 \pm 5$ & $1.1 \pm 0.5$ & $46.0 \pm 11.5$ & $5.2 \pm 0.9$ & $353.2 \pm 12.2$ & $93 \pm 49$ & $0.28 \pm 0.19$ & $31 \pm 39$ \\
\hline P2 & $53 \pm 6$ & $76 \pm 14$ & $0.3 \pm 0.1$ & $58.8 \pm 2.9$ & $3.8 \pm 1.9$ & $422.6 \pm 61.2$ & $37 \pm 7$ & $0.25 \pm 0.05$ & $9 \pm 2$ \\
\hline P3 & $16 \pm 2,79 \pm 2$ & $47 \pm 13$ & $1.9 \pm 0.3$ & $62.4 \pm 20.0$ & $13.7 \pm 1.1$ & $580.5 \pm 14.0$ & $60 \pm 29$ & $0.21 \pm 0.05$ & $12 \pm 1$ \\
\hline
\end{tabular}

1. Mixed layer depth calculated after Rintoul and Trull (2001); see Mongin et al., 2011 for discussion of 2 mixed layers at P3.

2. Euphotic depth and integrated Chl $a$ from Westwood et al. (2011).

3. Chl $a$ measurements at $10 \mathrm{~m}$ from Pearce et al. (2011)

4. Surface POC concentrations from Niskin bottle samples (Trull and Davies, unpublished).

5. Primary production estimates as discussed in detail by Cavagna et al. (2011), large std. dev. at P1 is due to different water masses.

6. $f$-Ratio $=$ nitrate uptake $/ \mathrm{N}$-uptake, $\mathrm{NPP}=\mathrm{C}$-uptake $\times f$-ratio.
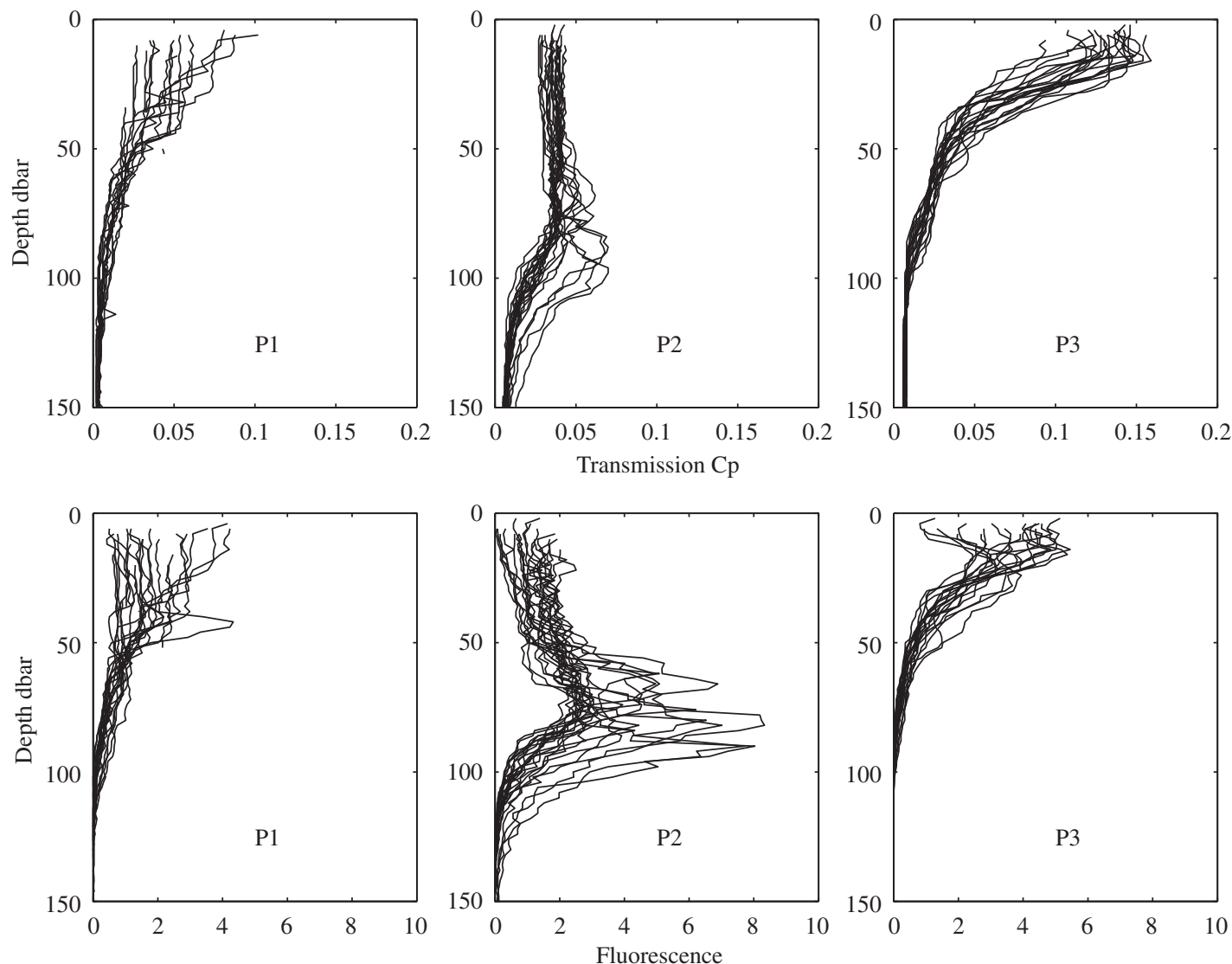

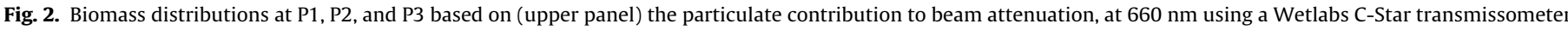

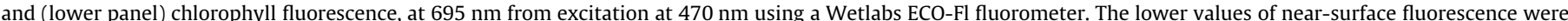
obtained during daylight, and reflect insolation quenching. 
site P2 (Table 1$)$. Low $f$-ratios $(<0.3)$ at all stations indicate that regenerated production dominated over new production (Cavagna et al., 2011, Table 1). Similarly, net community production estimates from $02 / A r$ supersaturations indicated higher values in the SAZ than the PFZ (Cassar et al., 2011).

There was some evidence for varying bottom-up controls on phytoplankton production among the three sites. At all three process stations mixed layer nitrate and phosphate were sufficient to not limit phytoplankton growth (nitrate: $5.5,24.3$, and $5.0 \mu \mathrm{M}$, phosphate: $0.22,1.58$, and $0.52 \mu \mathrm{M}$, at P1, P2, and P3, respectively) but silicate concentrations were low enough to affect diatom growth (0.29, 0.77, and 0.71 $\mu \mathrm{M}$, at P1, P2, and P3, respectively, Bowie et al., 2011). At P1, Fv/Fm values were low ( $<0.5$, Cheah et al., 2011; Petrou et al., 2011), and primary production was likely to have been limited by Fe, and possibly also silicic acid. At P2, Fv/Fm values were higher (0.58), but iron/phosphate ratios were suggestive of iron limitation (Lannuzel et al., 2011), and the deep mixed layer suggestive of light limitation (Doblin et al., 2011). At P3, there was no indication of Fe limitation from iron/phosphate ratios or Fv/Fm values (0.58; Cheah et al., 2011; Lannuzel et al., 2011; Petrou et al., 2011).

Plankton communities also differed among the three sites in several ways. In the SAZ (P1 and P3) the biomass generally consisted of non-diatoms (de Salas et al., 2011), although at P1 beside nanoflagellates a lightly silicified Thalassiosira sp. was also abundant. P3 was dominated by cyanobacteria and heterotrophic dinoflagellates (de Salas et al., 2011). At the PFZ site P2 a deep chlorophyll maximum occurred just below the euphotic depth but above the mixed layer (compare Table 1, Fig. 2 and Westwood et al., 2011) and was characterised mainly of heavily silicified diatoms and nanoflagellates (de Salas et al., 2011). Bacterial and viral abundances were higher in the SAZ than the PFZ and highest at P3 (Evans et al., 2011). There were no mesozooplankton population studies carried out during SAZSense, but grazing clearance rates from deckboard incubations suggest high micro-zooplankton grazing pressure, sufficient to remove $82 \%, 67 \%$, and $42 \%$ of primary production at $\mathrm{P} 1, \mathrm{P} 3$, and $\mathrm{P} 2$, respectively (Pearce et al., 2011).

\subsection{Collection of sinking particles using free-drifting sediment traps}

Three types of sediment traps were deployed, on separate arrays, as shown in Table 2. All three arrays were similar in their overall design and consisted of a surface float beneath which the respective traps were suspended by an elastic link that dampens wave motions. Details of the array design and evidence of its ability to isolate wave motions during rough weather are available by Trull et al. (2008), although the SAZ-Sense deployments differed slightly by not including drogues at depth, because the traps themselves act in this capacity. Weather conditions for the P1 and P2 deployments were rough, although more benign at P3. Pressure sensors mounted on the deepest trap on each array indicated that the traps remained at fixed depth, within the $\sim 4 \mathrm{~m}, 5 \mathrm{~min}$ resolution of the pressure sensor records. Drift of the traps was slow $\left(<10 \mathrm{~cm} \mathrm{~s}^{-1}\right)$ at P1 and P3 in the SAZ, and higher at P2 in the Antarctic Circumpolar Current (up to $23 \mathrm{~cm} \mathrm{~s}^{-1}$ ). These drift rates were similar to water velocities estimated from the shipboard acoustic Doppler current metre, and suggest very low water velocities relative to the traps (of the order of a few $\mathrm{cm} \mathrm{s}^{-1}$ ), and thus large hydrodynamic artefacts in the particle collections were not expected (Buesseler et al., 2007b).

To obtain bulk component fluxes (particulate organic carbon, biogenic silica, and biogenic carbonates), we deployed at each station a single cylindrical trap with an internal conical funnel at its base (Technicap, La Turbie, France, model PPS3/3) at $150 \mathrm{~m}$ depth with a collection area of $0.125 \mathrm{~m}^{2}$ that collected samples into a carousel of 12 cups over a period of $6 \mathrm{~d}$. All cups were filled with brine with salinity of $\sim 52$ psu, made by freezing filtered $(0.2 \mu \mathrm{m}$ pore size) surface seawater. Some cups were also preserved with mercuric chloride $\left(1 \mathrm{~g} \mathrm{~L}^{-1}\right)$ as a biocide (Table 3 ). Most cups were analysed for component fluxes, with some cups used separately for trace metal studies (no poison added).

To estimate particle sinking rates, we deployed at each station two indented rotating sphere (IRS) traps (described in detail by Peterson et al., 2005, 2009; Trull et al., 2008) at 170 and $320 \mathrm{~m}$ depth on a second separate array. The IRS traps (Prime Focus, Inc. Seattle, WA, USA), have cylindrical tubes $\left(0.018 \mathrm{~m}^{2}\right.$ collection area) that collect particles onto dimpled spheres, which then rotate to transfer the particles into a settling tube for separation into 11 fractions based on their sinking velocities (as shown in Table 4). The sum of these fractions also provides a measurement of the total flux. The IRS traps collected particles for a total of $5 \mathrm{~d}$. As in previous deployments, we programmed the IRS traps to collect the 11th sample in a way that checks the functioning of the trap (Trull et al., 2008), and filled the cups with the same brine and mercuric chloride concentrations as for the PPS3/3 trap.

Table 2

Deployment schedules for the free-drifting sediment trap arrays.

\begin{tabular}{|c|c|c|c|c|c|c|c|c|}
\hline Site & Array & Trap depths (m) & Event & Time (UTC) & Latitude & Longitude & Duration (d) & Drift (km) \\
\hline \multirow[t]{6}{*}{ P1 } & \multirow[t]{2}{*}{ Gel traps } & \multirow[t]{2}{*}{$140,190,240,290$} & Deploy & 22-Jan-07 04:30 & $46^{\circ} 20.50^{\prime} \mathrm{S}$ & $140^{\circ} 34.60^{\prime} \mathrm{E}$ & \multirow[t]{2}{*}{1.08} & \multirow[t]{2}{*}{13} \\
\hline & & & Recover & 23-Jan-07 06:29 & $46^{\circ} 27.35^{\prime} S$ & $140^{\circ} 32.23^{\prime} \mathrm{E}$ & & \\
\hline & \multirow[t]{2}{*}{ PPS3/3 trap } & \multirow[t]{2}{*}{150} & Deploy & 22-Jan-07 00:57 & $46^{\circ} 25.38^{\prime} \mathrm{S}$ & $140^{\circ} 29.67^{\prime} \mathrm{E}$ & \multirow[t]{2}{*}{6.34} & \multirow[t]{2}{*}{22} \\
\hline & & & Recover & 28-Jan-07 21:15 & $46^{\circ} 36.80^{\prime} \mathrm{S}$ & $140^{\circ} 25.65^{\prime} \mathrm{E}$ & & \\
\hline & \multirow[t]{2}{*}{ IRS traps } & \multirow[t]{2}{*}{170,320} & \multirow{2}{*}{\multicolumn{4}{|c|}{$\begin{array}{l}\text { Technical problems } \\
\text { Precluded deployment }\end{array}$}} & & \\
\hline & & & & & & & & \\
\hline \multirow[t]{6}{*}{ P2 } & \multirow[t]{2}{*}{ Gel traps } & \multirow[t]{2}{*}{$140,190,240,290$} & Deploy & 31-Jan-07 16:15 & $54^{\circ} 59.90^{\prime} \mathrm{S}$ & $145^{\circ} 56.90^{\prime} \mathrm{E}$ & \multirow[t]{2}{*}{1.14} & \multirow[t]{2}{*}{16} \\
\hline & & & Recover & 1-Feb-07 19:37 & $54^{\circ} 03.45^{\prime} \mathrm{S}$ & $146^{\circ} 10.44^{\prime} \mathrm{E}$ & & \\
\hline & \multirow[t]{2}{*}{ PPS3/3 trap } & \multirow[t]{2}{*}{150} & Deploy & 31-Jan-07 14:48 & $54^{\circ} 00.03^{\prime} \mathrm{S}$ & $145^{\circ} 58.05^{\prime} \mathrm{E}$ & \multirow[t]{2}{*}{6.13} & \multirow[t]{2}{*}{121} \\
\hline & & & Recover & 5-Feb-07 22:40 & $54^{\circ} 34.96^{\prime} \mathrm{S}$ & $147^{\circ} 32.94^{\prime} \mathrm{E}$ & & \\
\hline & \multirow[t]{2}{*}{ IRS traps } & \multirow[t]{2}{*}{170,320} & Deploy & 31-Jan-07 19:33 & $53^{\circ} 59.85^{\prime} \mathrm{S}$ & $145^{\circ} 54.50^{\prime} \mathrm{E}$ & \multirow[t]{2}{*}{5.75} & \multirow[t]{2}{*}{93} \\
\hline & & & Recover & 6-Feb-04 04:24 & $54^{\circ} 26.60^{\prime} \mathrm{S}$ & $147^{\circ} 06.62^{\prime} \mathrm{E}$ & & \\
\hline \multirow[t]{6}{*}{ P3 } & \multirow[t]{2}{*}{ Gel traps } & \multirow[t]{2}{*}{$140,190,240,290$} & Deploy & 10-Feb-07 23:26 & $45^{\circ} 32.10^{\prime} \mathrm{S}$ & $153^{\circ} 11.48^{\prime} \mathrm{E}$ & \multirow[t]{2}{*}{0.97} & \multirow[t]{2}{*}{9} \\
\hline & & & Recover & 11-Feb-07 22:45 & $45^{\circ} 29.44^{\prime} \mathrm{S}$ & $153^{\circ} 17.52^{\prime} \mathrm{E}$ & & \\
\hline & \multirow[t]{2}{*}{ PPS3/3 trap } & \multirow[t]{2}{*}{150} & Deploy & 10-Feb-07 20:01 & $45^{\circ} 29.99^{\prime} \mathrm{S}$ & $153^{\circ} 11.94^{\prime} \mathrm{E}$ & \multirow[t]{2}{*}{6.06} & \multirow[t]{2}{*}{49} \\
\hline & & & Recover & 16-Feb-07 23:39 & $45^{\circ} 24.52^{\prime} \mathrm{S}$ & $153^{\circ} 48.82^{\prime} \mathrm{E}$ & & \\
\hline & \multirow[t]{2}{*}{ IRS traps } & 170,320 & Deploy & 10-Feb-07 21:41 & $45^{\circ} 31.04^{\prime} \mathrm{S}$ & $153^{\circ} 11.87^{\prime} \mathrm{E}$ & 5.89 & 47 \\
\hline & & & Recover & 16-Feb-07 15:21 & $45^{\circ} 35.34^{\prime} \mathrm{S}$ & $153^{\circ} 47.09^{\prime} \mathrm{E}$ & & \\
\hline
\end{tabular}

1. Trap depths were constant within the $4 \mathrm{~m}$ depth and $5^{\prime}$ time resolutions of the sensor on the deepest trap on each array. 
Table 3

Particle fluxes at $150 \mathrm{~m}$ depth from the 6-d free-drifting deployments of the 12-cup-carousel cylindrical PPS3/3-trap.

\begin{tabular}{|c|c|c|c|c|c|c|c|c|c|c|c|}
\hline $\begin{array}{l}\text { Cup } \\
\text { i.d. no. }\end{array}$ & $\begin{array}{l}\text { Cup } \\
\text { opening } \\
\text { date }\end{array}$ & $\begin{array}{l}\text { Cup } \\
\text { opening } \\
\text { time }\end{array}$ & $\begin{array}{l}\text { Cup duration } \\
\text { hours }\end{array}$ & $\begin{array}{l}\text { Cup } \\
\text { poison } \\
\text { type }\end{array}$ & 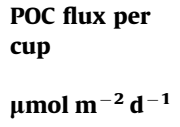 & 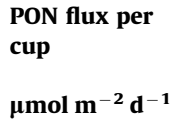 & 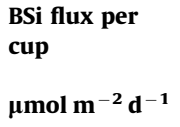 & 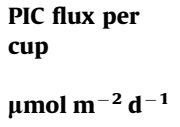 & $\begin{array}{l}\text { POC/PON } \\
\text { ratio } \\
\mathrm{mol} / \mathrm{mol}\end{array}$ & $\begin{array}{l}\mathrm{POC} / \mathrm{BSi} \\
\text { ratio } \\
\mathrm{mol} / \mathrm{mol}\end{array}$ & $\begin{array}{l}\mathrm{POC} / \mathrm{PIC} \\
\text { ratio } \\
\mathrm{mol} / \mathrm{mol}\end{array}$ \\
\hline \multicolumn{12}{|l|}{ P 1} \\
\hline 3 & 23 Jan & 07:00 & 12 & None & 1921 & 269 & 141 & 109 & 7.1 & 14 & 18 \\
\hline 4 & 23 Jan & $19: 00$ & 12 & None & 2589 & 380 & 108 & 138 & 6.8 & 24 & 19 \\
\hline 5 & 24 Jan & 07:00 & 12 & $\begin{array}{l}\text { Merc. } \\
\text { chlor. }\end{array}$ & 1842 & 301 & 98 & 80 & 6.1 & 19 & 23 \\
\hline 6 & 24 Jan & $19: 00$ & 12 & $\begin{array}{l}\text { Merc. } \\
\text { chlor. }\end{array}$ & 1648 & 227 & 56 & 95 & 7.3 & 29 & 17 \\
\hline 9 & 26 Jan & 07:00 & 12 & None & 4201 & 603 & 267 & 410 & 7.0 & 16 & 10 \\
\hline 10 & 26 Jan & $19: 00$ & 12 & None & 6145 & 959 & 662 & 1318 & 6.4 & 9 & 5 \\
\hline 11 & 27 Jan & 07:00 & 12 & $\begin{array}{l}\text { Merc. } \\
\text { chlor. }\end{array}$ & 2587 & 382 & 169 & 301 & 6.8 & 15 & 9 \\
\hline \multirow[t]{3}{*}{12} & 27 Jan & $19: 00$ & 12 & $\begin{array}{l}\text { Merc. } \\
\text { chlor. }\end{array}$ & 5777 & 2219 & 128 & 423 & 2.6 & 45 & 14 \\
\hline & & & & Mean & 3339 & 667 & 204 & 359 & 5.0 & 16 & 9 \\
\hline & & & & Std. dev. & 1805 & 671 & 196 & 412 & 1.5 & 11 & 6 \\
\hline \multicolumn{12}{|l|}{ P 2} \\
\hline 3 & 23 Jan & 07:00 & 12 & None & 2385 & 378 & 3154 & 360 & 6.3 & 0.76 & 7 \\
\hline 4 & 23 Jan & $19: 00$ & 12 & None & 1897 & 281 & 1945 & 165 & 6.7 & 0.98 & 11 \\
\hline 5 & 24 Jan & 07:00 & 12 & $\begin{array}{l}\text { Merc. } \\
\text { chlor. }\end{array}$ & 1238 & 187 & 2220 & 223 & 6.6 & 0.56 & 6 \\
\hline 6 & 24 Jan & $19: 00$ & 12 & $\begin{array}{l}\text { Merc. } \\
\text { chlor. }\end{array}$ & 1765 & 253 & 2516 & 260 & 7.0 & 0.70 & 7 \\
\hline 9 & 26 Jan & 07:00 & 12 & None & 3751 & 535 & 1866 & 436 & 7.0 & 2.01 & 9 \\
\hline \multirow[t]{3}{*}{10} & 26 Jan & $19: 00$ & 12 & $\begin{array}{l}\text { Merc. } \\
\text { chlor. }\end{array}$ & 1649 & 240 & 2299 & 266 & 6.9 & 0.72 & 6 \\
\hline & & & & Mean & 2114 & 312 & 2333 & 285 & 6.8 & 0.91 & 7 \\
\hline & & & & Std. dev. & 884 & 126 & 467 & 98 & 0.3 & 0.53 & 2 \\
\hline \multicolumn{12}{|l|}{ P 3} \\
\hline 3 & 23 Jan & 07:00 & 12 & $\begin{array}{l}\text { Merc. } \\
\text { chlor. }\end{array}$ & 1708 & 296 & 25 & 105 & 5.8 & 69 & 16 \\
\hline 4 & 23 Jan & $19: 00$ & 12 & $\begin{array}{l}\text { Merc. } \\
\text { chlor. }\end{array}$ & 685 & 132 & 18 & 44 & 5.2 & 39 & 15 \\
\hline 5 & 24 Jan & 07:00 & 12 & None & 553 & 86 & 14 & 23 & 6.4 & 40 & 24 \\
\hline 6 & 24 Jan & $19: 00$ & 12 & None & 680 & 119 & 13 & 43 & 5.7 & 52 & 16 \\
\hline 9 & 26 Jan & 07:00 & 12 & $\begin{array}{l}\text { Merc. } \\
\text { chlor. }\end{array}$ & 880 & 127 & 19 & 43 & 6.9 & 47 & 20 \\
\hline 10 & 26 Jan & $19: 00$ & 12 & $\begin{array}{l}\text { Merc. } \\
\text { chlor. }\end{array}$ & 688 & 104 & 11 & 44 & 6.6 & 61 & 15 \\
\hline 11 & 27 Jan & 07:00 & 12 & None & 1073 & 153 & 13 & 65 & 7.0 & 81 & 16 \\
\hline \multirow[t]{3}{*}{12} & 27 Jan & $19: 00$ & 12 & None & 594 & 86 & 11 & 33 & 6.9 & 53 & 18 \\
\hline & & & & Mean & 858 & 138 & 15 & 50 & 6.2 & 55 & 17 \\
\hline & & & & Std. dev. & 382 & 68 & 5 & 25 & 1 & 14 & 3 \\
\hline
\end{tabular}

1. Times are UTC, local time was UTC $+11 \mathrm{~h}$, and thus cups ran dusk to dawn (18:00-06:00) and dawn to dusk (06:00-18:00) daily.

2. Particles were washed through a $350 \mu \mathrm{m}$ screen to remove zooplankton and collected on a $1 \mathrm{~mm}$ silver filter.

3. Trace metal fluxes were measured in cup nos. 1, 2, 7, and 8 for each trap, respectively, and additionally in cups 11 and 12 at P2 and are reported by Bowie et al. (2009).

To collect intact particles for optical examination of their sizes and shapes, we deployed four individual cylindrical polyacrylamide gel traps. The gel traps had a collection area of $0.011 \mathrm{~m}^{2}$ and were deployed along a third separate array at each station at 140 , 190,240 , and $290 \mathrm{~m}$ depths. To avoid overloading the gels with particles, these deployments were limited to a single day, during the first day of the deployments of the PPS3/3 and IRS traps. The preparation of the polyacrylamide traps and subsequent processing has been previously described (Ebersbach and Trull, 2008).

\subsection{Sample analyses}

\subsubsection{Chemical analysis}

The PPS3/3 trap samples were washed through a $350 \mu \mathrm{m}$ screen to remove zooplankton, using $0.8 \mu \mathrm{m}$ pore size $\mathrm{GF} / \mathrm{F}$ filtered seawater, and the fraction passing the screen was collected by low vacuum filtration onto $25 \mathrm{~mm}$ diameter $1 \mu \mathrm{m}$ pore size silver membrane filters (Sterlitech, Concord, MA, USA). The IRS trap samples were filtered in the same way without previous screening (the IRS ball greatly reduces swimmer contamination), although swimmers (zooplankton) were subsequently removed from the filters using forceps. For both the IRS and PPS3/3 trap samples, the filters (after being dried in a clean oven at $60{ }^{\circ} \mathrm{C}$ ) were sub-sampled in a flow-bench with a $5 \mathrm{~mm}$ diameter pre-cleaned stainless steel punch to provide aliquots for biogenic silica by alkaline digestion and spectrometry. The PPS $3 / 3$ trap sample filters were then punched for POC and PON analyses by catalytic combustion elemental analysis after de-carbonation $\left(20 \mu \mathrm{L}\right.$ of $2 \mathrm{M} \mathrm{HCl}$ followed by drying at $60^{\circ} \mathrm{C}$ for $48 \mathrm{~h}$ ) and the remainder of the filter was used for PIC determination by acidification in a closed module and coulometric $\mathrm{CO}_{2}$ titration. The IRS trap filters were encapsulated and de-carbonated with no further sub-sampling before elemental analysis because of the very small amount of material collected. Methods are detailed by 
Table 4

Particle fluxes separated by sinking rate from the 5-d free-drifting deployments of the IRS traps at 170 and $320 \mathrm{~m}$ depth.

\begin{tabular}{|c|c|c|c|c|c|c|c|c|c|c|c|c|c|c|}
\hline $\begin{array}{l}\text { Trap } \\
\text { depth } \\
\text { m }\end{array}$ & $\begin{array}{l}\text { Cup i.d. } \\
\text { no. }\end{array}$ & $\begin{array}{l}\text { Sinking } \\
\text { rate } \\
\text { m d }^{-1}\end{array}$ & $\begin{array}{l}\text { Cup } \\
\text { duration } \\
\text { min }\end{array}$ & 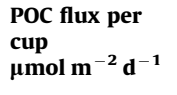 & 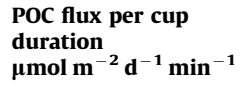 & $\begin{array}{l}\text { POC flux } \\
\text { fraction } \\
\%\end{array}$ & $\begin{array}{l}\text { POC flux } \\
\text { cumulative } \\
\%\end{array}$ & $\begin{array}{l}\text { corr-POC flux } \\
\text { fraction } \\
\%\end{array}$ & $\begin{array}{l}\text { corr-POC flux } \\
\text { cumulative } \\
\%\end{array}$ & 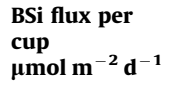 & $\begin{array}{l}\text { BSi flux per cup } \\
\text { duration } \\
\mu \mathrm{mol} \mathrm{m}^{-2} \mathrm{~d}^{-1} \min ^{-1}\end{array}$ & $\begin{array}{l}\text { BSi flux } \\
\text { fraction } \\
\%\end{array}$ & $\begin{array}{l}\text { BSi flux } \\
\text { cumulative } \\
\%\end{array}$ & $\begin{array}{l}\mathrm{POC} / \mathrm{BSi} \\
\text { ratio } \\
\mathrm{mol} / \mathrm{mol}\end{array}$ \\
\hline \multicolumn{3}{|l|}{ P2 } & \multicolumn{2}{|c|}{ Begin collection } & \multicolumn{2}{|l|}{ 31-Jan-07 21:00 } & \multicolumn{2}{|c|}{ End collection } & \multicolumn{6}{|l|}{ 4-Feb-07 21:00 } \\
\hline \multirow[t]{12}{*}{$170 \mathrm{~m}$} & 1 & $>850$ & 1 & 54 & 54 & 3 & 3 & 0 & 0 & 14 & 14 & 1 & 1 & 4.0 \\
\hline & 2 & 410 & 1 & 318 & 318 & 17 & 20 & 21 & 21 & 372 & 372 & 27 & 28 & 0.9 \\
\hline & 3 & 205 & 2 & 106 & 53 & 6 & 26 & 4 & 26 & 40 & 20 & 3 & 30 & 2.7 \\
\hline & 4 & 137 & 2 & 85 & 42 & 5 & 31 & 3 & 29 & 39 & 20 & 3 & 33 & 2.2 \\
\hline & 5 & 102 & 2 & 85 & 42 & 5 & 35 & 3 & 31 & 34 & 17 & 2 & 36 & 2.5 \\
\hline & 6 & 51 & 8 & 108 & 13 & 6 & 41 & 5 & 36 & 96 & 12 & 7 & 43 & 1.1 \\
\hline & 7 & 26 & 16 & 188 & 12 & 10 & 52 & 11 & 47 & 151 & 9.4 & 11 & 53 & 1.2 \\
\hline & 8 & 13 & 32 & 176 & 5.5 & 10 & 61 & 10 & 57 & 158 & 4.9 & 11 & 65 & 1.1 \\
\hline & 9 & 6 & 64 & 152 & 2.4 & 8 & 70 & 8 & 65 & 115 & 1.8 & 8 & 73 & 1.3 \\
\hline & 10 & 2.3 & 231 & 504 & 2.2 & 28 & 97 & 35 & 100 & 377 & 1.6 & 27 & 100 & 1.3 \\
\hline & 11 & 2.3 & 1 & 49 & 49 & 3 & 100 & 0 & 100 & 1 & 0.7 & 0 & 100 & 74 \\
\hline & Total & & & 1826 & & & & & & 1395 & & & & 1.3 \\
\hline \multirow[t]{12}{*}{$320 \mathrm{~m}$} & 1 & $>850$ & 1 & 77 & 77 & 7 & 7 & 4 & 4 & 3 & 2.8 & 0 & 0 & 28 \\
\hline & 2 & 410 & 1 & 106 & 106 & 9 & 16 & 10 & 13 & 36 & 36 & 6 & 6 & 3.0 \\
\hline & 3 & 205 & 2 & 138 & 69 & 12 & 28 & 16 & 29 & 68 & 34 & 11 & 18 & 2.0 \\
\hline & 4 & 137 & 2 & 76 & 38 & 7 & 35 & 4 & 33 & 18 & 9.1 & 3 & 21 & 4.2 \\
\hline & 5 & 102 & 2 & 94 & 47 & 8 & 43 & 7 & 40 & 40 & 20 & 7 & 27 & 2.3 \\
\hline & 6 & 51 & 8 & 93 & 12 & 8 & 51 & 7 & 47 & 87 & 11 & 14 & 42 & 1.1 \\
\hline & 7 & 26 & 16 & 118 & 7.4 & 10 & 61 & 12 & 59 & 57 & 3.5 & 9 & 51 & 2.1 \\
\hline & 8 & 13 & 32 & 85 & 2.7 & 7 & 69 & 5 & 64 & 57 & 1.8 & 9 & 60 & 1.5 \\
\hline & 9 & 6 & 64 & 128 & 2.0 & 11 & 80 & 14 & 78 & 68 & 1.1 & 11 & 72 & 1.9 \\
\hline & 10 & 2.3 & 231 & 170 & 0.7 & 15 & 95 & 22 & 100 & 166 & 0.7 & 27 & 99 & 1.0 \\
\hline & 11 & 2.3 & 1 & 58 & 58 & 5 & 100 & 0 & 100 & 7 & 6.6 & 1 & 100 & 8.7 \\
\hline & Total & & & 1144 & & & & & & 607 & & & & 1.9 \\
\hline \multicolumn{3}{|l|}{ P3 } & \multicolumn{2}{|c|}{ Begin collection } & \multicolumn{2}{|l|}{ 10-Feb-07 23:00 } & \multicolumn{2}{|c|}{ End collection } & 15-Feb-07 23:00 & & & & & \\
\hline $170 \mathrm{~m}$ & $\begin{array}{l}1-11 \\
\text { Total }\end{array}$ & $>2.3$ & 360 & $\begin{array}{l}864 \\
864\end{array}$ & 2.4 & 100 & 100 & & & $\begin{array}{l}11 \\
\mathbf{1 1}\end{array}$ & 0.03 & 100 & 100 & $\begin{array}{l}76 \\
76\end{array}$ \\
\hline $320 \mathrm{~m}$ & 1 & $>850$ & 1 & 95 & 95 & 51 & 51 & & & $<1$ & $<1$ & 0 & 0 & $>95$ \\
\hline & $2-11$ & $2.3-850$ & 359 & 90 & 0.3 & 49 & 100 & & & 5 & 0.01 & 100 & 100 & 20 \\
\hline & Total & & & 185 & & & & & & 5 & & & & 37 \\
\hline
\end{tabular}

1. Times are UTC, local time was UTC $+11 \mathrm{~h}$.

2. All particles were collected on $1 \mathrm{~mm}$ silver filters, and the very few zooplankton present in a few fractions were removed manually.

3. Corr-POC flux and corr-POC cumulative flux are values corrected for possible carry-over of slow-sinking particles from one IRS cycle to the next-see Section 4. 
Trull et al. (2008). Sub-sampling introduces variability of $10-20 \%$ from inhomogeneous filter coverage that well exceeds the analytical uncertainties of these methods (Trull et al., 2008).

\subsubsection{Particle properties from the polyacrylamide gels}

Immediately after recovery, the gel cups were removed from the tubes. Within a few hours of recovery the gels were photographed under low magnification (6.5-50) against an etchedglass grid of 36 cells $\left(12.5 \times 14 \mathrm{~mm}\right.$ each). Gels were stored at $2{ }^{\circ} \mathrm{C}$ until further investigations in the laboratory onshore. The low magnification images were processed using image analysis software to obtain statistics of particle abundances and forms (Ebersbach and Trull, 2008). We divided the particles into 5 classes of particles: fluff-aggregates, faecal-aggregates, phytocells, cylindrical faecal pellets, and ovoid faecal pellets (see Table 5, Fig. 3). Assuming that particles were more or less evenly distributed over the gel surface, 10 grid cells per gel were analysed $\left(16.8 \mathrm{~cm}^{2}\right.$, which corresponds to one fifth of the collection area) and projected to the gel area.

To allow size comparisons for particles of different shapes, we calculated equivalent spherical diameters (esd) from the observed areas $\left(\mathrm{esd}=2(\operatorname{area} / \pi)^{0.5}\right)$. We set a minimum particle size for analysis of $0.001 \mathrm{~mm}^{2}$ ( $36 \mu \mathrm{m}$ esd), because few particles were smaller than this, and because this ensured that gel thickness and refractive index variations were not mis-interpreted as 'particles'. For each particle type, volumes were estimated from the imaged areas using the geometric approximations given by Ebersbach and Trull (2008), i.e. aggregates and phyto-cells were regarded as spheres, cylindrical pellets as cylinders, and ovoid pellets as ellipsoids.

To convert volume flux into carbon flux, we adopted carbon contents of $0.057 \mathrm{mg} \mathrm{C} \mathrm{mm}^{-3}$ for faecal pellets (Gonzalez and Smetacek, 1994), and applied the parameterisation for carbon conversion factors used in our previous work (Ebersbach and Trull, 2008). That formulation is based on the fractal decrease of carbon contents with size observed for large coastal marine snow

Table 5

Particle categories based on microscopic observations of the polyacrylamide gels.

\begin{tabular}{|c|c|c|}
\hline Category & Appearance & Size range $\left(\mu \mathrm{m}^{3}\right)$ \\
\hline \multicolumn{3}{|l|}{ Aggregates } \\
\hline Fluff-aggregate (flu) & Amorphous shapes, fluffy, brownish in colour & $1-5400$ \\
\hline Faecal-aggregate (fae) & $\begin{array}{l}\text { Composed of distinctly shaped smaller particles, especially } \\
\text { faecal pellets. Brownish in colour }\end{array}$ & $0.07-1000$ \\
\hline $\begin{array}{l}\text { Phytoplankton cells } \\
\text { phyto-cell (phy) }\end{array}$ & Diatom chains or individual diatom cells & $0.07-1$ \\
\hline \multicolumn{3}{|l|}{ Faecal pellets } \\
\hline cylindrical pellet (cyl) & Intact cylindrically formed faecal pellet, brown colour & $0.04-1600$ \\
\hline Ovoid pellet (ovo) & Intact faecal pellet of oval from, dark brown/black & $0.06-100$ \\
\hline
\end{tabular}
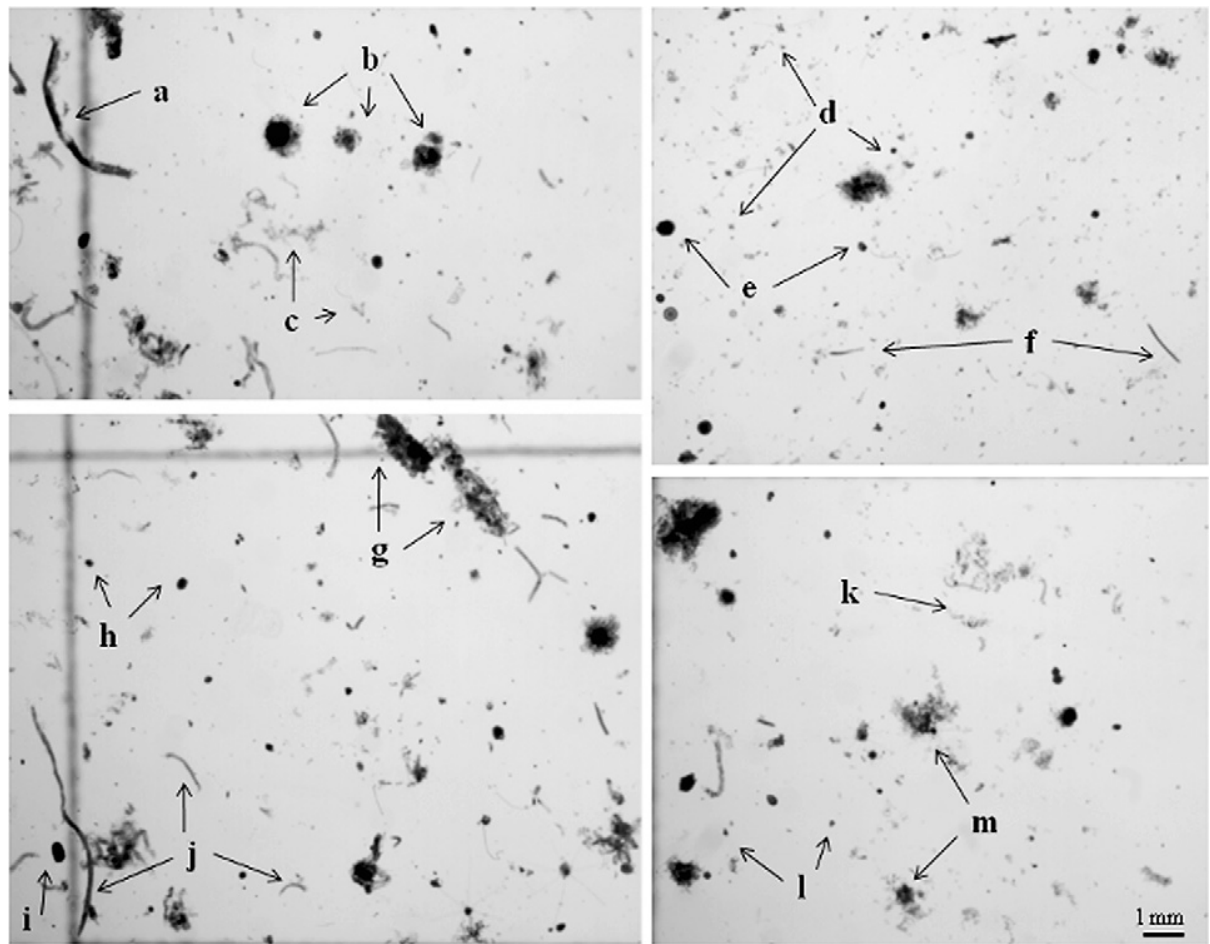

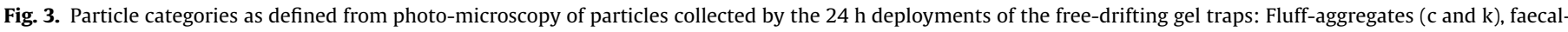

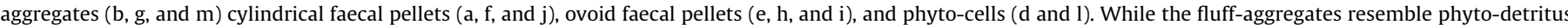

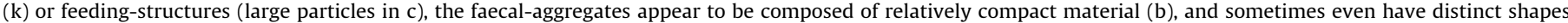

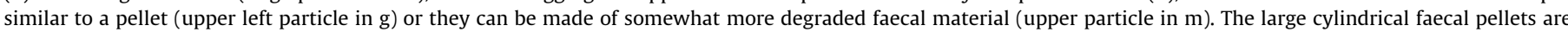

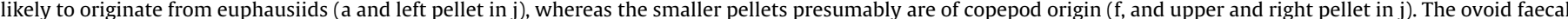

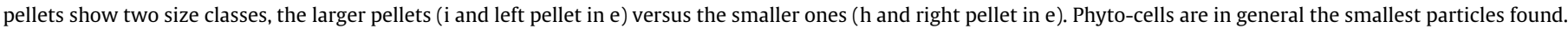


aggregates (Alldredge, 1998), but scaled to match up with solid geometry estimates for phytoplankton at lower sizes, where extrapolation of the large aggregate results would yield unrealistically high carbon contents. This scaled coastal aggregate relationship yields values ranging from $0.014 \mathrm{mg} \mathrm{C} \mathrm{mm}^{-3}$ for small aggregates $\left(0.004 \mathrm{~mm}^{3}\right)$ to $0.0015 \mathrm{mg} \mathrm{C} \mathrm{mm}^{-3}$ for very large aggregates $\left(10 \mathrm{~mm}^{3}\right)$. Because the phyto-cells were mostly provided by diatoms we used a power-law relation compiled for extant diatoms: $\log _{10} C=\log _{10} a+b \log _{10} V$ (with $C=$ carbon content in mg per cell and $V=$ cell volume in $\mathrm{mm}^{3}$, estimated from images (see above)), with $\log _{10} a=-0.541$ and $b=0.881$ (Menden-Deuer and Lessard, 2000). This results in carbon contents that range from 0.035 to $0.016 \mathrm{mg} \mathrm{C} \mathrm{mm}^{-3}$ for our smallest ( $36 \mu \mathrm{m}$ esd) to largest ( $300 \mu \mathrm{m}$ esd) diatoms. For comparison we also calculated POC fluxes using a new algorithm based on correlating suspended particle size distributions with deep ocean sediment trap fluxes (Guidi et al., 2008). The correlation reflects the combined influence of particle size on POC content and on sinking rate, and separating out the sinking rate dependence leads to a POC content as a function of size that can be applied to our gel trap particles $\left(\mathrm{POC}=0.38 \mathrm{esd}^{2.55}\right.$ with
POC in $\mathrm{mg} \mathrm{m}^{-3}$ for esd in $\mathrm{mm}$ ). This yields slightly lower POC fluxes at P1 and P2, and slightly higher estimates at P3 than our algorithm, but does not change the relative values of the fluxes among the three process stations.

\section{Results}

\subsection{Geochemical fluxes from the PPS3/3 and IRS traps}

\subsubsection{Flux magnitudes}

POC fluxes at $150 \mathrm{~m}$ depth collected by the PPS3/3 trap were approximately 3000,2000 , and $1000 \mu \mathrm{mol} \mathrm{m}{ }^{-2} \mathrm{~d}^{-1}$ at process stations $\mathrm{P} 1, \mathrm{P} 2$, and $\mathrm{P} 3$, respectively (Table 3). At each station, the POC flux varied by a factor of 3 across the individual 12-h samples. This variability was not correlated with the time of collection (day versus night), or with the presence or absence of poison in the trap cups. All the flux samples had POC/PON ratios close to the canonical Redfield ratio for phytoplankton of 6.6 , with the exception of sample 12 from process station P1 with a POC/PON of 2.6 despite displaying no conspicuous difference in its macroscopic character. PIC fluxes were about one magnitude lower than POC fluxes and decreased more strongly from P1 to P3 whereby the POC/PIC ratio at P3 was twice as high as at P1 and P2 (Table 3).
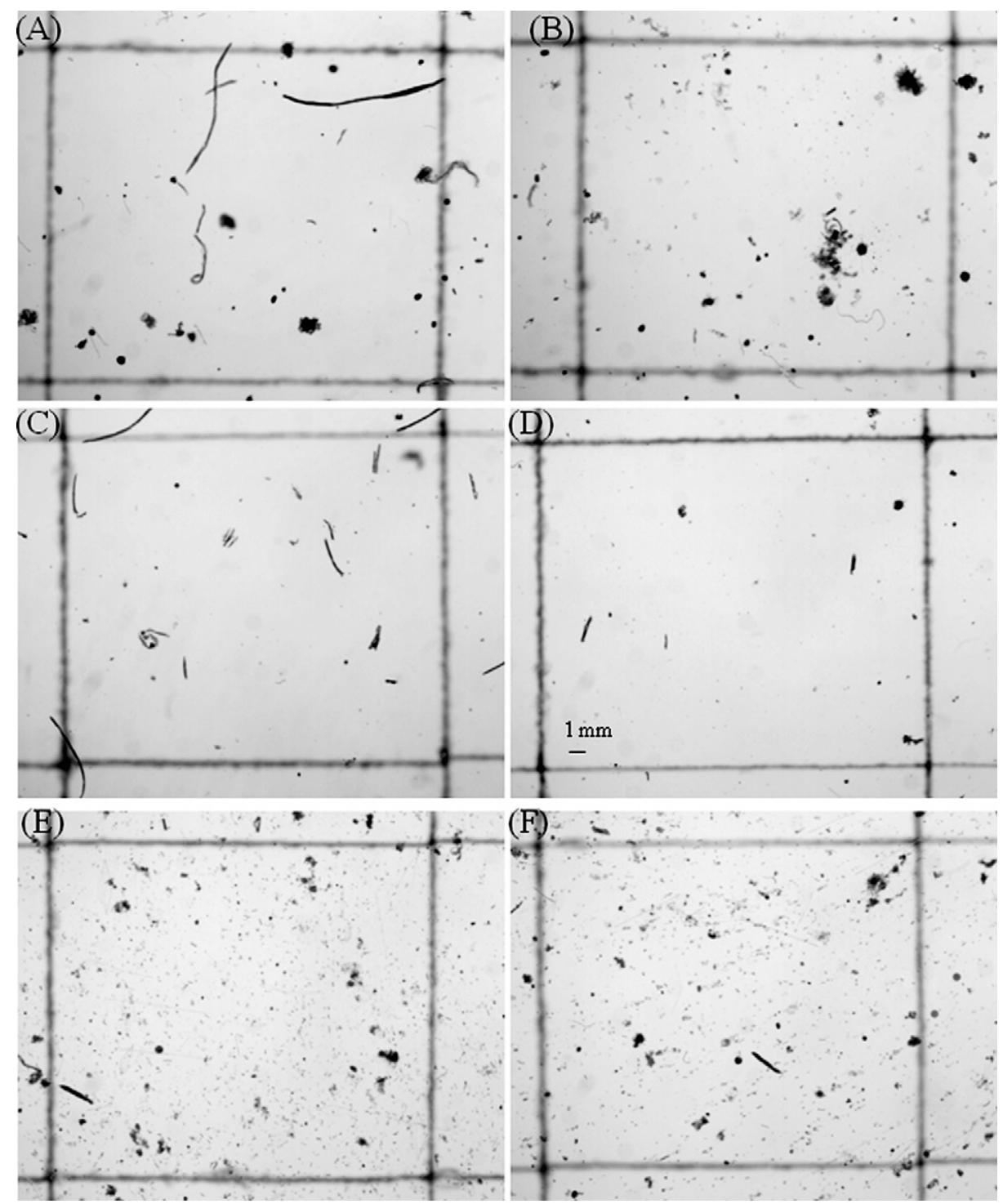

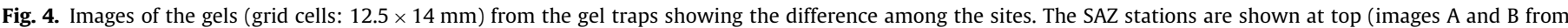

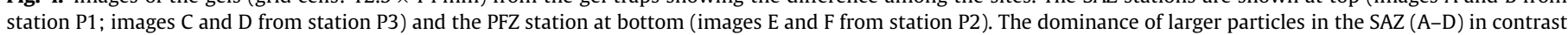

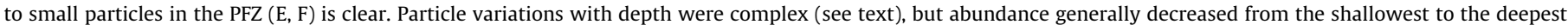
trap at each station, as shown here from left to right (images A, C, E from 140 m; images B, D, F from 290 m). 
Biogenic silica fluxes varied more strongly between stations than those of POC, with the highest flux occurring in the PFZ (averaging ca. $2000 \mu \mathrm{mol} \mathrm{Si} \mathrm{m}{ }^{-2} \mathrm{~d}^{-1}$ at P2), much lower fluxes in the western SAZ and lowest values in the eastern SAZ (less than one-tenth and one-hundredth of the PFZ flux at P1 and P3, respectively). The high BSi flux at P2 was not accompanied by high POC, and this site exhibited the lowest, POC/BSi ratio (Table 3). The low surface silicate at all sites (Cavagna et al., 2011) together with high BSi fluxes at P2 underline the importance of silicate and therefore diatoms for export controls at the PFZ-site. In contrast, the low BSi fluxes and high POC/BSi ratios at the SAZ-sites P1 and P3 suggests that diatoms were not important for $\mathrm{POC}$ flux in the SAZ, where $\mathrm{CaCO}_{3}$ dominated biogenic mineral fluxes (Table 3). As for POC, BSi fluxes among the individual cups varied strongly, $\sim 2$-fold at P2 and P3, and more than 10 -fold at P1, and no correlations of BSi flux with time of collection or use of poison were evident

The IRS trap total fluxes (obtained by summing all sinking-rate fractions, Table 4) gave similar POC and BSi fluxes at $170 \mathrm{~m}$ depth to those obtained with the much larger diameter PPS $3 / 3$ trap at $150 \mathrm{~m}$ depth. This provides considerable encouragement that the fluxes were not strongly biased by flow past the traps, because this hydrodynamic bias is thought to vary strongly with trap diameter (Gust and Kozerski, 2000). It also suggests that potential biases from zooplankton entering the traps were accounted for, given that sieving of zooplankton from the poisoned and unpoisoned PPS3/3 trap cups gave similar results to the IRS trap in which zooplankton were excluded by the indented rotating sphere and direct removal using forceps.

\subsubsection{Fluxes as a function of sinking rates from the IRS traps}

Technical problems precluded deployment of the IRS traps at P1, and the low flux at P3 only allowed estimation of the total flux by combining the fractions (Table 4). Thus, separation of the particle flux into different sinking-rate fractions was only possible at $\mathrm{P} 2$, where sufficient material was obtained in all 11 sinking rate fractions to allow analysis of POC and BSi for both the 170 and $320 \mathrm{~m}$ depth traps (but not PON or PIC, Table 4). These data suggest that the POC (and BSi) flux was relatively evenly spread across the full range of sinking-rate fractions (with each containing $11 \%$ or less of the flux), but with somewhat higher fluxes in two fractions-a relatively fast sinking fraction (the $410-850 \mathrm{~m} \mathrm{~d}^{-1}$ fraction in the $170 \mathrm{~m}$ trap, and the $205-410 \mathrm{~m} \mathrm{~d}^{-1}$ fraction in the $320 \mathrm{~m}$ trap) and a relatively slow sinking fraction (the $2.3-26 \mathrm{~m} \mathrm{~d}^{-1}$ fraction at both depths). For the $170 \mathrm{~m}$ depth trap, this fast fraction contained $17 \%$ of the POC flux, and the slow fraction $28 \%$ of the POC flux. For the $320 \mathrm{~m}$ depth trap, the respective contributions were somewhat smaller ( $12 \%$ and $15 \%$, respectively), but still stood out as the two largest fractions.

\subsection{Particle characteristics from the gel traps}

\subsubsection{Classification of sinking particles}

The single day deployments of the gels yielded even coverage of particles across the gel surfaces, and sparse, well separated particle distributions optimal for image analysis. Different particle types were identifiable (Fig. 3, Table 5), including diatoms (mainly as chains but also a few individual cells), intact faecal pellets, and aggregates of these and other more amorphous materials. Within the faecal pellets cylindrical and ovoid pellets were distinguished. A wide range of aggregates was present (Figs. 4 and 5) and reflects the large variety of components that account for marine snow (Alldredge and Gotschalk, 1990). A minority of the aggregates appeared to be rather fluffy and will be referred to as fluff-aggregates. The others are either more compact or seem to be composed of smaller particles and will be referred to as faecal-aggregates (Table 5, Fig. 3).

\subsubsection{General characteristics of the particle fluxes}

Small particles were most abundant at every site, with numerical fluxes dropping by 4 orders of magnitude as size (esd) increased from 0.01 to $0.1 \mathrm{~cm}$ (Fig. 6). Nonetheless, the volume and carbon fluxes were mainly carried by mid-sized and larger particles (esd of 0.05 and $0.1 \mathrm{~cm}$, Figs. 7 and 8). The carbon flux was dominated by slightly smaller particles than the volume flux (compare Figs. 7 and 8), because the larger particles were assumed to have lower carbon densities (see Section 2.3.2). The overall importance of the large particles in controlling the carbon flux is emphasised by the cumulative carbon flux (Fig. 9). It clearly shows that the large particles that only make up $5-10 \%$ of the numerical flux provide more than half of the carbon flux.

\subsubsection{Differences in particle flux characteristics among the sites}

Total volume flux of particles from the gel traps was highest at P1, followed by P2 and P3 (Table 6). The carbon fluxes calculated from the images showed the same trend, $\mathrm{P} 1>\mathrm{P} 2>\mathrm{P} 3$, and decreased from around 10,000 to $600 \mu \mathrm{mol} \mathrm{C} \mathrm{m} \mathrm{m}^{-2} \mathrm{~d}^{-1}$ (Table 7). The sites also differed in the number and the nature of the particles observed. In terms of particle numbers, P2 had the highest flux, followed by P1 and P3 (Table 6). This was due to the very large number of very small particles (mainly phytoplankton cells) at P2 (Table 6, Fig. 6). The larger, flux-dominating particles were predominantly faecal-aggregates at all sites, followed by large cylindrical faecal pellets, with rarer occurrences of ovoid faecal pellets (as is apparent from the images in Fig. 4 and quantified in Table 6). Fluff-aggregates did not play a large role at any of the sites (Tables 6 and 7), although it is of course possible that fluffy material, such as phyto-detritus or feeding structures, were included within some of the less tightly

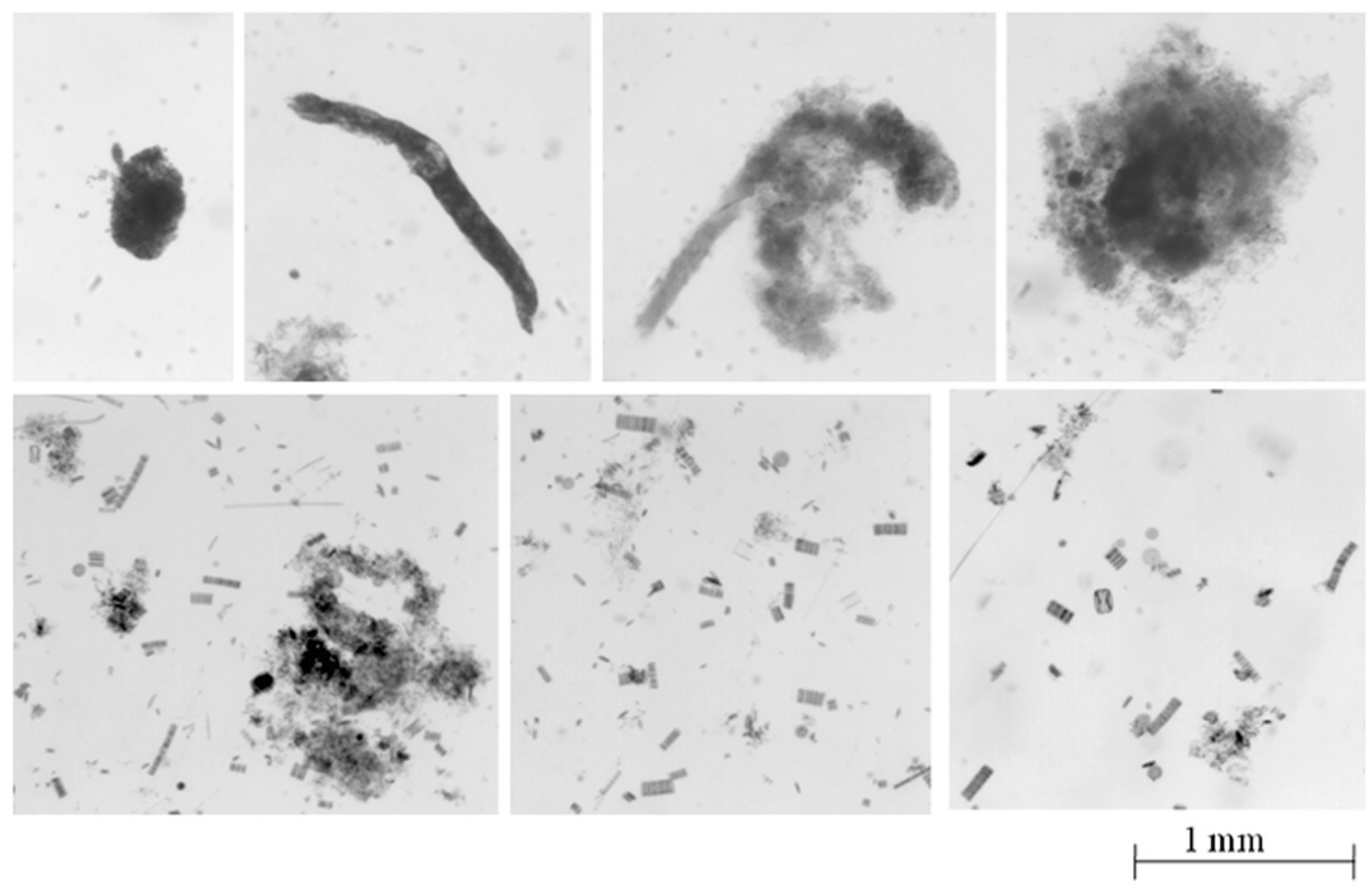

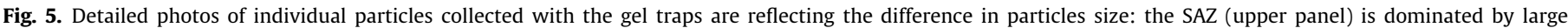

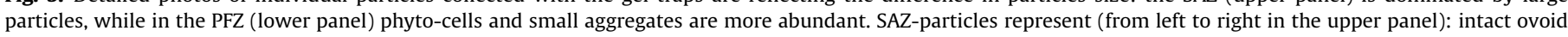

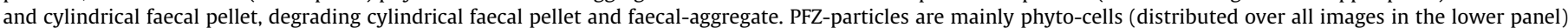
and small fluff-aggregates and fluffy faecal-aggregates (lower left image). Scale bar for all photos: $1 \mathrm{~mm}$. 


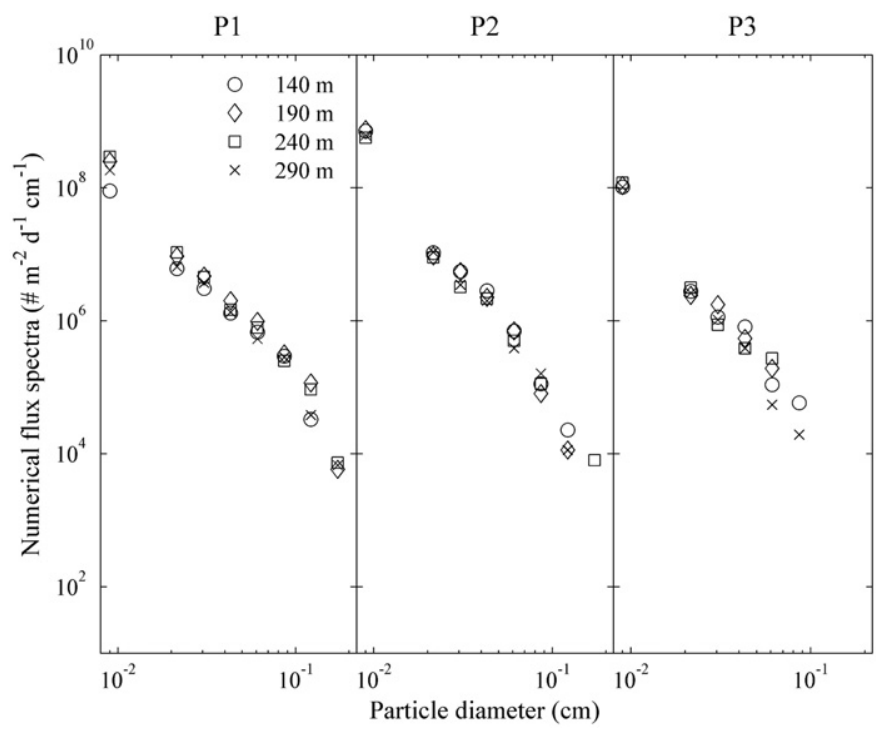

Fig. 6. Number flux spectra from the Gel-traps, indicating the variations with depth $(140,190,240$, and $290 \mathrm{~m})$.

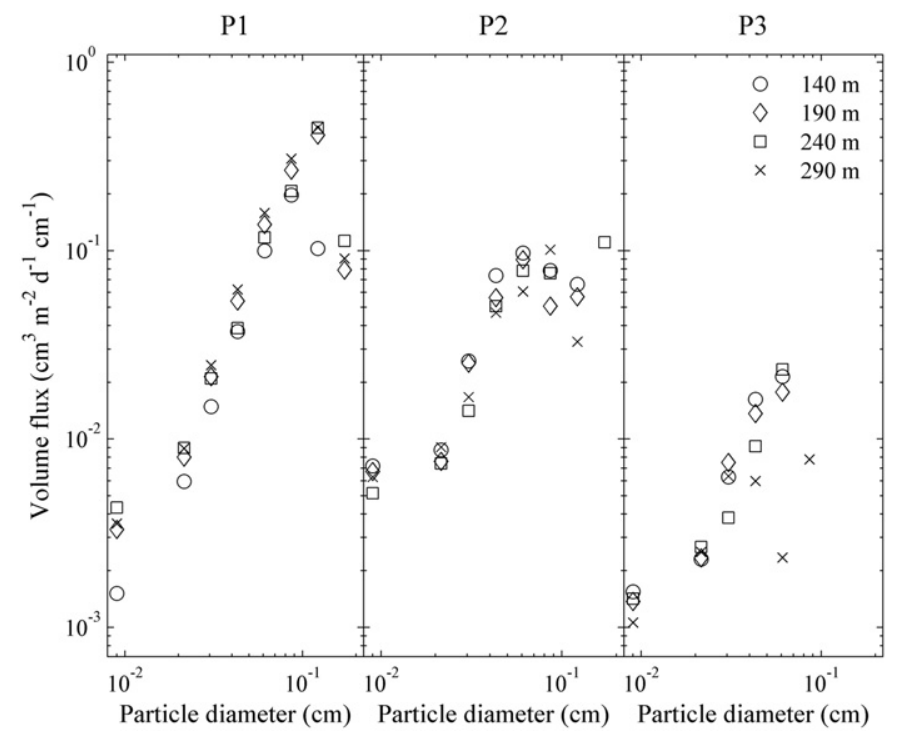

Fig. 7. Size fractioned volume flux spectra showing the greater importance of large particles to the volume flux than to the numerical flux (compare Fig. 6).

packed faecal-aggregates. Particle composition at P3 was similar to P1 in being dominated by faecal-aggregates and having a dearth of phyto-cells, but the dominance of the faecal-aggregates is somewhat reduced by the presence of cylindrical faecal pellets (Table 7).

The sizes of the particles within the different particle classes also varied among the sites. The faecal-aggregates were largest at P1, where their volumes were almost twice that of the faecal-aggregates at P2 and P3 (Table 9). Fluffaggregates were four to ten times smaller than faecal-aggregates; they were larger at P2 than P1, and absent at P3. The largest cylindrical pellets were found at P3, followed by P1 (half the volume or length) and then P2 (circa one order of magnitude smaller). Pellets at P2 were somewhat wider (lower aspect ratios) than at P1 and P3. Within the category of ovoid faecal pellets, at least two size classes can be distinguished (see particles labelled e, h, and i in Fig. 3) and at P1 more of the larger ones were found (Table 8). Phyto-cells did not differ appreciably in size between the sites.

\subsection{Variations of flux and particle composition with depth}

A decrease of the POC flux with increasing depth (from 170 to $320 \mathrm{~m}$ ) was recognisable in the IRS traps at P2 and P3: by almost half at P2, and even more strongly to one-fifth at P3 (Table 4). The greater depth resolution of the gels as

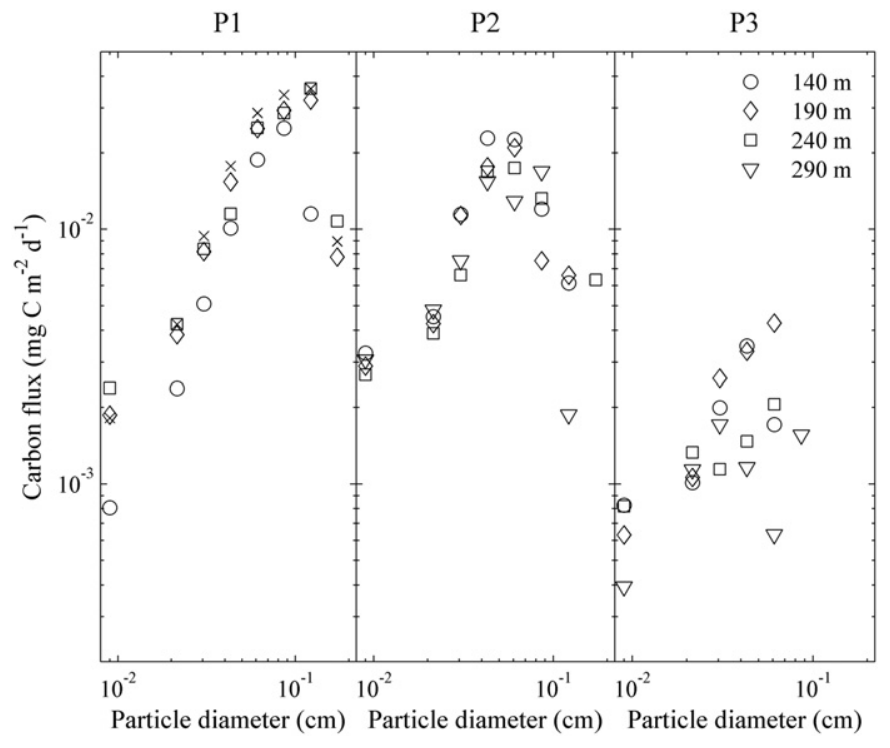

Fig. 8. Estimated POC flux spectra from the piece-wise volume to POC conversion function that incorporates carbon content estimates for phytoplankton, faecal pellets, and aggregates (see Section 2.3.2). This function shifts the peak carbon flux to somewhat smaller particle sizes than the peak volume flux (because of the increasing porosity of large aggregates as modelled by fractal geometry).

compared to the IRS traps (Table 2) gives further insights into the flux variation with depth. In particular, the shallowest gel trap revealed distinct differences among the stations. At the SAZ-sites P1 and P3, the flux at $140 \mathrm{~m}$ was lower than the flux at $190 \mathrm{~m}$, which then decreased slightly by $290 \mathrm{~m}$. Whereas P2 (PFZ) showed a relatively high flux at $140 \mathrm{~m}$ in comparison to $190 \mathrm{~m}$ and then a continuous strong decrease with depth.

Except at the shallowest depths at P1, the total volume flux decreased with increasing depths (Fig. 7, Table 6). In regard to total carbon flux, variations with depth were complex (Fig. 8, Table 7). At P2 the faecal-aggregate fluxes, and thus the carbon fluxes, dropped by one half from the surface to $290 \mathrm{~m}$ depth, whereas at P1 and P3 changes in the faecal-aggregate and carbon fluxes were much less pronounced (Table 7). At P2, where phyto-cells were important, their carbon flux declined with depth. For the faecal pellets no trends with depth were recognisable.

\section{Discussion}

\subsection{Overview}

We first discuss the sediment trap results, beginning with technical aspects of trap function, followed by comparisons of the flux magnitudes for the different trap types and the 3 process stations (Section 4.2). Next we examine the particle characteristics as observed in the gel traps (Section 4.3). Finally, we consider the probable ecosystem controls on the particle fluxes, including comparing the SAZ-Sense results to other studies (Section 4.4).

\subsection{Vertical export determined by sediment traps}

\subsubsection{Functioning of the sediment traps}

Hydrodynamic effects can impair trapping efficiency (e.g. Gust and Kozerski, 2000; Buesseler et al., 2007b), but because of the very low relative water velocities for all three sediment trap types (see Section 2.2), this influence is likely to have been minimal. This view is corroborated by the even coverage of particles across the surface of the gels, and the fine structures preserved within them. It also appears that the entry of zooplankton into the traps is unlikely to have strongly biased the flux results for two reasons: (i) the PPS3/3 results were indistinguishable between poisoned and unpoisoned cups, and (ii) the total fluxes from the IRS trap with its zooplankton excluding indented rotating sphere, 


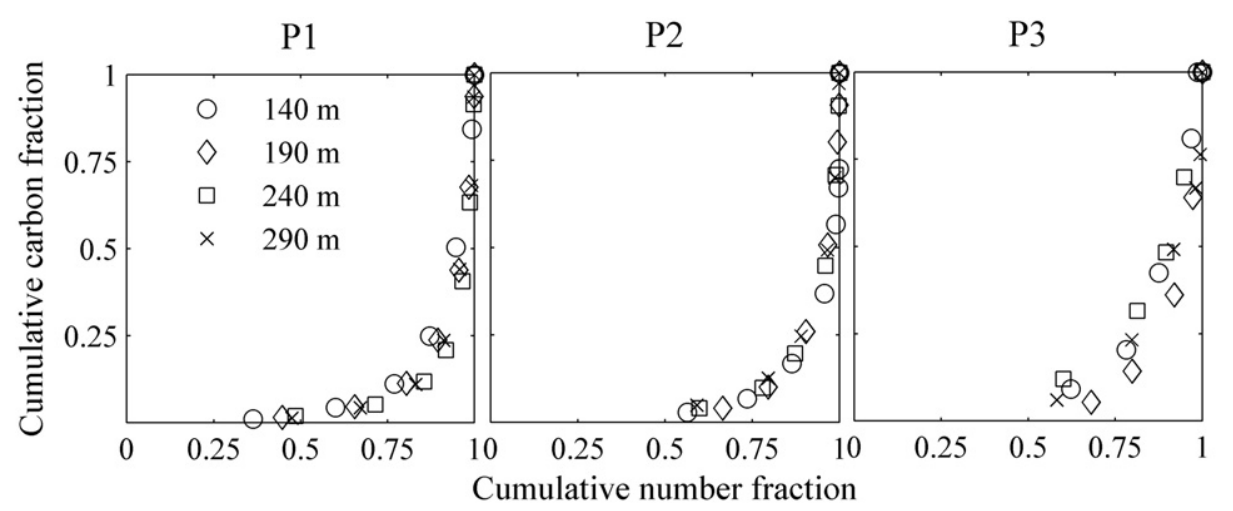

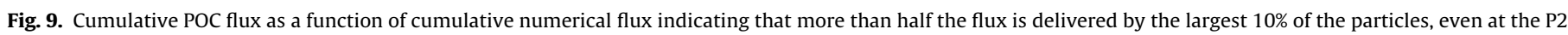
site where small particles were abundant (see Fig. 4).

Table 6

Particle number and volume fluxes and fractional contributions from different particle types.

\begin{tabular}{|c|c|c|c|c|c|c|c|c|c|c|c|c|c|}
\hline \multirow[t]{2}{*}{ Site } & \multirow{2}{*}{$\begin{array}{l}\text { Depth } \\
\text { m }\end{array}$} & \multirow{2}{*}{$\begin{array}{l}\text { Numerical flux } \\
\# \mathbf{m}^{-2} \mathbf{d}^{-1}\end{array}$} & \multicolumn{5}{|c|}{ Fractional contributions (\%) } & \multirow{2}{*}{$\begin{array}{l}\text { Volume flux } \\
\mathrm{cm}^{3} \mathrm{~m}^{-2} \mathrm{~d}^{-1}\end{array}$} & \multicolumn{5}{|c|}{ Fractional contributions (\%) } \\
\hline & & & flu & fae & cyl & ovo & phy & & flu & fae & cyl & ovo & phy \\
\hline \multirow[t]{4}{*}{ P1 } & 140 & 32 & 2 & 36 & 5 & 15 & 40 & 0.46 & 0 & 82 & 17 & 2 & 0 \\
\hline & 190 & 73 & 4 & 28 & 1 & 11 & 55 & 0.98 & 0 & 95 & 4 & 1 & 0 \\
\hline & 240 & 82 & 0 & 29 & 1 & 12 & 58 & 0.96 & 0 & 98 & 1 & 1 & 0 \\
\hline & 290 & 53 & 0 & 28 & 2 & 17 & 54 & 0.94 & 0 & 93 & 4 & 2 & 0 \\
\hline \multirow[t]{4}{*}{ P2 } & 140 & 177 & 0 & 17 & 2 & 7 & 74 & 0.92 & 0 & 93 & 6 & 0 & 0 \\
\hline & 190 & 183 & - & 15 & 5 & 9 & 71 & 0.29 & - & 91 & 7 & 1 & 0 \\
\hline & 240 & 139 & 1 & 16 & 2 & 7 & 74 & 0.34 & 0 & 65 & 32 & 2 & 0 \\
\hline & 290 & 151 & 0 & 17 & 1 & 7 & 74 & 0.27 & 0 & 81 & 17 & 1 & 0 \\
\hline \multirow[t]{4}{*}{ P3 } & 140 & 27 & - & 21 & 7 & 18 & 53 & 0.05 & - & 37 & 60 & 2 & 0 \\
\hline & 190 & 29 & - & 20 & 5 & 27 & 47 & 0.04 & - & 81 & 16 & 1 & 0 \\
\hline & 240 & 31 & - & 18 & 7 & 11 & 64 & 0.04 & - & 30 & 67 & 2 & 0 \\
\hline & 290 & 26 & - & 15 & 4 & 16 & 65 & 0.03 & - & 70 & 24 & 5 & 0 \\
\hline
\end{tabular}

1. -: No particle of this type observed.

2. Particle types as defined in Table 5.

Table 7

POC fluxes and fractional contributions from identified particle types, as estimated from imaged areas.

\begin{tabular}{|c|c|c|c|c|c|c|c|c|c|c|c|c|}
\hline \multirow{2}{*}{$\begin{array}{l}\text { Site } \\
\text { i.d. }\end{array}$} & \multirow{2}{*}{$\begin{array}{l}\text { Depth } \\
\text { m }\end{array}$} & \multirow{2}{*}{ 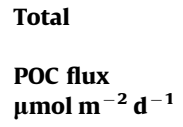 } & \multicolumn{2}{|l|}{ flu } & \multicolumn{2}{|l|}{ fae } & \multicolumn{2}{|l|}{ cyl } & \multicolumn{2}{|l|}{ ovo } & \multicolumn{2}{|l|}{ phy } \\
\hline & & & $\begin{array}{l}\text { POC flux } \\
\mu \mathrm{mol} \mathrm{m}{ }^{-2} d^{-1}\end{array}$ & $\begin{array}{l}\text { Fraction } \\
\%\end{array}$ & $\begin{array}{l}\text { POC flux } \\
\mu \mathrm{mol} \mathrm{\mathbf {m } ^ { - 2 }} \mathrm{d}^{-1}\end{array}$ & $\begin{array}{l}\text { Fraction } \\
\%\end{array}$ & $\begin{array}{l}\text { POC flux } \\
\mu \mathrm{mol} \mathrm{m^{-2 }} \mathbf{d}^{-1}\end{array}$ & $\begin{array}{l}\text { Fraction } \\
\%\end{array}$ & $\begin{array}{l}\text { POC flux } \\
\mu \mathrm{mol} \mathrm{m} \mathbf{m}^{-2} \mathrm{~d}^{-1}\end{array}$ & $\begin{array}{l}\text { Fraction } \\
\%\end{array}$ & $\begin{array}{l}\text { POC flux } \\
\mu \mathrm{mol} \mathrm{m} \mathbf{m}^{-2} \mathrm{~d}^{-1}\end{array}$ & $\begin{array}{l}\text { Fraction } \\
\%\end{array}$ \\
\hline \multirow[t]{4}{*}{ P1 } & 140 & 6141.9 & 8.9 & 0 & 5731.7 & 93 & 363.9 & 6 & 37.1 & 1 & 0.4 & 0 \\
\hline & 190 & $10,280.9$ & 38.6 & 0 & 9991.6 & 97 & 187.8 & 2 & 61.9 & 1 & 1.0 & 0 \\
\hline & 240 & $10,567.2$ & 5.1 & 0 & $10,482.0$ & 99 & 33.0 & 0 & 45.5 & 1 & 1.3 & 0 \\
\hline & 290 & 8103.2 & 0.0 & 0 & 7907.0 & 97 & 133.0 & 2 & 62.1 & 1 & 0.8 & 0 \\
\hline \multirow[t]{4}{*}{ P2 } & 140 & 9508.2 & 2.5 & 0 & 9219.8 & 97 & 266.9 & 3 & 15.7 & 0 & 3.2 & 0 \\
\hline & 190 & 5928.5 & - & - & 5815.1 & 98 & 96.9 & 2 & 13.7 & 0 & 2.9 & 0 \\
\hline & 240 & 5578.3 & 11.0 & 0 & 5008.3 & 90 & 528.5 & 9 & 28.3 & 1 & 2.2 & 0 \\
\hline & 290 & 5196.5 & 16.9 & 0 & 4936.1 & 95 & 226.3 & 5 & 14.5 & 0 & 2.7 & 0 \\
\hline \multirow[t]{4}{*}{ P3 } & 140 & 752.3 & - & - & 611.1 & 81 & 136.5 & 18 & 4.2 & 1 & 0.5 & 0 \\
\hline & 190 & 988.9 & - & - & 951.9 & 96 & 33.7 & 4 & 2.9 & 0 & 0.4 & 0 \\
\hline & 240 & 568.0 & - & - & 434.7 & 77 & 128.5 & 23 & 4.3 & 1 & 0.5 & 0 \\
\hline & 290 & 549.1 & - & - & 513.1 & 94 & 29.5 & 5 & 5.9 & 1 & 0.5 & 0 \\
\hline
\end{tabular}

1. -: No particle of this type observed.

2. Particle types as defined in Table 5.

were only slightly lower than the fluxes from the open-mouthed PPS3/3 trap, and within the uncertainties defined by the standard deviations of the individual cups (Tables 3 and 4).

The fidelity of the separation of the sinking particles by settling speed by the IRS trap requires careful evaluation. Ideally, when operated in sinking-rate mode, it transfers particles from the indented-rotating-sphere into the settling tube, where they enter successive cups in the carousel according to their sinking rates (Peterson et al., 2005). For the IRS rotation interval and carousel cycle duration of $6 \mathrm{~h}$ used here, this results in fractions 
Table 8

Median characteristics of the particle types.

\begin{tabular}{|c|c|c|c|c|c|c|c|c|c|c|c|c|c|c|c|c|}
\hline \multirow[t]{2}{*}{ Site i.d. } & \multirow{2}{*}{$\begin{array}{l}\text { Depth } \\
\text { m }\end{array}$} & \multicolumn{3}{|l|}{ flu } & \multicolumn{3}{|l|}{ fae } & \multicolumn{3}{|l|}{ cyl } & \multicolumn{3}{|l|}{ ovo } & \multicolumn{3}{|l|}{ phy } \\
\hline & & $\begin{array}{l}\text { vol } \\
\mu \mathrm{m}^{3}\end{array}$ & $\begin{array}{l}\text { esd } \\
\text { mm }\end{array}$ & $\begin{array}{l}\text { ar } \\
\%\end{array}$ & $\begin{array}{l}\text { vol } \\
\mu \mathrm{m}^{3}\end{array}$ & $\begin{array}{l}\text { esd } \\
\text { mm }\end{array}$ & $\begin{array}{l}\text { ar } \\
\%\end{array}$ & $\begin{array}{l}\text { vol } \\
\mu \mathrm{m}^{3}\end{array}$ & $\begin{array}{l}\mathbf{l} \\
\mathbf{m m}\end{array}$ & $\begin{array}{l}\text { ar } \\
\%\end{array}$ & $\begin{array}{l}\text { vol } \\
\mu \mathrm{m}^{3}\end{array}$ & $\begin{array}{l}\mathbf{l} \\
\mathbf{m m}\end{array}$ & $\begin{array}{l}\text { ar } \\
\%\end{array}$ & $\begin{array}{l}\text { vol } \\
\mu \mathrm{m}^{3}\end{array}$ & $\begin{array}{l}\text { esd } \\
\text { mm }\end{array}$ & $\begin{array}{l}\text { ar } \\
\%\end{array}$ \\
\hline \multirow[t]{4}{*}{ P1 } & 140 & 0.6 & 1.1 & 60 & 8.4 & 2.5 & 58 & 5.3 & 0.60 & 19 & 3.5 & 0.2 & 76 & 0.2 & 0.1 & 62 \\
\hline & 190 & 0.6 & 1.1 & 56 & 7.4 & 2.4 & 56 & 5.9 & 0.62 & 22 & 2.1 & 0.2 & 76 & 0.1 & 0.6 & 62 \\
\hline & 240 & 0.6 & 1.1 & 65 & 4.5 & 2.1 & 59 & 4.9 & 0.54 & 23 & 1.9 & 0.2 & 78 & 0.1 & 0.6 & 61 \\
\hline & 290 & - & - & - & 6.2 & 2.3 & 59 & 5.3 & 0.64 & 17 & 2.5 & 0.2 & 98 & 0.1 & 0.6 & 61 \\
\hline \multirow[t]{4}{*}{ P2 } & 140 & 1.0 & 1.2 & 50 & 4.1 & 2.0 & 63 & 0.5 & 0.23 & 24 & 1.4 & 0.1 & 77 & 0.1 & 0.6 & 59 \\
\hline & 190 & - & - & - & 4.3 & 2.0 & 60 & 0.2 & 0.15 & 28 & 0.9 & 0.1 & 76 & 0.1 & 0.6 & 59 \\
\hline & 240 & 0.6 & 1.1 & 56 & 3.9 & 2.0 & 62 & 0.3 & 0.17 & 27 & 1.1 & 0.1 & 76 & 0.1 & 0.6 & 59 \\
\hline & 290 & 0.8 & 1.1 & 54 & 3.5 & 1.9 & 62 & 0.3 & 0.18 & 25 & 1.4 & 0.1 & 77 & 0.1 & 0.6 & 60 \\
\hline \multirow[t]{4}{*}{ P3 } & 140 & - & - & & 2.8 & 1.8 & 56 & 13.9 & 0.90 & 13 & 0.6 & 0.1 & 79 & 0.1 & 0.6 & 63 \\
\hline & 190 & - & - & & 4.3 & 2.0 & 57 & 7.9 & 0.76 & 14 & 0.5 & 0.1 & 79 & 0.1 & 0.6 & 64 \\
\hline & 240 & - & - & & 3.0 & 1.8 & 54 & 9.1 & 0.73 & 14 & 1.1 & 0.1 & 78 & 0.1 & 0.6 & 63 \\
\hline & 290 & - & - & & 4.9 & 2.1 & 56 & 11.4 & 0.81 & 16 & 1.0 & 0.1 & 77 & 0.1 & 0.6 & 65 \\
\hline
\end{tabular}

1. -: No particle of this type observed.

2. Particle types as defined in Table 5 .

3. Volumes (vol), equivalent spherical diameters (esd), lengths (l), aspect ratios (ar)=width/length.

with sinking rates ranging from $>850$ to $\sim 2.3 \mathrm{~m} \mathrm{~d}^{-1}$ (Table 3 ). The effectiveness of this separation requires evaluation. A particular concern is the possibility that very slow-sinking particles remain in the funnel beyond the duration of a full carousel rotation ( $6 \mathrm{~h}$ in this study and our previous work; Trull et al., 2008), and are thus transferred into the subsequent cycle where they could be erroneously collected into the carousel fractions that collect faster sinking particles. Programming the collection interval of the last cup in the cycle (\#11) to have the same one minute duration as the first cup in the subsequent cycle (\#1) provides some quality control on this issue (Trull et al., 2008).

As shown in Table 3, for the IRS trap at P2, the POC flux collected in the 11 th cup at 170 and $320 \mathrm{~m}$ depths were similar and these amounts are only slightly less than the POC fluxes collected by the first cups for these traps. This suggests that carryover was significant. If so, the fluxes observed in the other cups should be reduced for this contribution. For example, the flux to each cup could be considered to represent the sum of the contribution from the most recent IRS rotation and a background of a steady flux of slow sinking particles (Armstrong et al., 2009). However, there are aspects of the flux distribution over the 11 fractions that suggest that this is an over-simplification. The POC flux per cup duration for many sinking rate fractions is less than the POC flux to the 11 th cups (e.g. cups 6-10 for both the 170 and $320 \mathrm{~m}$ deployments). Indeed, the POC flux per cup duration for the 11th cups is much larger than that for the preceding 10th cups. This suggests that the high fluxes per cup duration in the 11 th cups may be induced by the carousel rotation, perhaps by causing particles that have accumulated at the mouth of the cup to enter the cup. In our previous work, we found large colonial radiolaria in the 11th cups, and attributed the high fluxes per cup duration to their unusual presence (Trull et al., 2008). These or other unusual organisms were not discernable in the present study, but the material in the 11th cups had high POC/BSi ratios in comparison to the preceding 10th cups, suggesting that the material entering the 11 th cups was different in character. One way to rationalise these results is to consider that very slowly sinking material has not completely left the settling tube within $6 \mathrm{~h}$, and the motion of the carousel as it turns to cup \#11 and then again to cup \#1 causes some or all of the this material to be moved further along the settling tube and into the cups. Thus the carry-over quantity to subsequent cups would be an aliquot related to the carousel motion, rather than a steady background flux. In other words, correction for carry-over should be equal to (or less than) the 11th cup fluxes, rather than depending on the duration that the cups were open.

Correcting for carry-over in this way does not change the overall character of the distribution of POC flux across the sinking-rate fractions, rather it emphasises the initial perspective from the uncorrected data - that the flux is spread across the full range of sinking fractions, but with an elevated flux from two classes of particles - a relatively fast sinking fraction, and a very slow sinking fraction (see corrected flux values in Table 4).

\subsubsection{Flux characteristics of the three sites}

In terms of POC flux, the same sequence was observed for all the trap types deployed ( $1>P 2>P 3)$, although the flux estimates vary in magnitude for the different trap types (Tables 3, 4, and 7). In comparison to the PPS3/3 and IRS traps, which tend to be similar, the gel traps gave the highest POC flux values for each site, and also a wider range in relative fluxes among the sites than for the measured POC fluxes in the PPS $3 / 3$ and IRS traps. The POC fluxes from PPS $3 / 3$ and IRS traps were determined directly via geochemical analysis, while the gel trap flux estimates were based on converting particle volume as identified through microscopic observations into units of carbon (see Section 2.3.2). Because most of the flux is carried by faecalaggregates at all three sites, it is likely that the conversion factor for this particle type is the cause of this difference. The fact that the faecal-aggregates are somewhat inhomogeneous as they might originate from processed material (see Section 4.3) supports this conclusion. At P3 where faecal-aggregates contribute much less to total volume flux due to their overall smaller size and numbers (Tables 6 and 8), their relative contribution to POC flux is still similar to the other stations (Table 7) suggesting that carbon content of the larger faecal-aggregates might be overestimated. This perspective is consistent with the small differences between our estimates and those obtained with the algorithm from Guidi et al. (2008). At P1, where large faecalaggregates were dominant, our POC flux was higher than that from the Guidi et al. algorithm, as it was to a lesser degree at P2. At P3, in contrast, our flux appears to be underestimated, which might be explained by the high abundance of small and relatively compact particles. 
The complex flux variations with depth as estimated from the gel traps (see Section 3.3) could be affected by small scale variations in time and space (notice also the relatively high standard deviation of up to $1 / 3$ of the mean for POC flux with PP3/3 traps, Table 3 ). In addition they could reflect the introduction of biases from the volume-to-carbon algorithms used in estimates from the gel traps (discussed above).

Furthermore, when comparing fluxes among the three sites, we have to keep in mind, that the collected material is derived from the mesopelagic (see Table 2 for trap deployment depths). The largest flux attenuation is often found higher up in the water column (for instance at the pycnocline at 50-60 m depths (Reigstad et al., 2008)). Since the euphotic depth was between 34 and $90 \mathrm{~m}$ (Table 1) during this study, the sinking particles underwent heavy processing before they reached the traps (140 $\mathrm{m}$ or deeper, Table 2). Certainly, some of the particulate matter was remineralised between the base of the mixed layer and $140 \mathrm{~m}$ (Cassar et al., 2011). Thus the collected particles represent the mesopelagic flux and differ considerably from surface particles leaving the euphotic zone.

\subsection{Composition of particles}

The particle categories identified from the gel traps (see Section 3.2.1, Fig. 3, and Table 5) provide some insights into the forms of the sinking material during SAZ-Sense. However, it is important to keep in mind that inferences based on these observations are uncertain because the formation pathways remain unknown. For example, since marine snow aggregates capture surrounding particles as they travel through the water column (Alldredge and Silver, 1988) the identification of the collected material cannot necessarily identify the ecological pathways that initiated vertical export. Bacterial degradation may also have altered particle composition and shape (Azam, 1998). Moreover, the sinking particles collected at $140 \mathrm{~m}$ depth or deeper (Table 2) have already left the euphotic zone, where most of the flux alteration occurred.

Based on their structural appearance the aggregates were separated into fluff-aggregates and faecal-aggregates (Fig. 3, Table 5). Different fluff-aggregates resembled different types of aggregates found during earlier studies and might possibly include phytodetritus, flocculent faecal pellets or larvacean houses (e.g. Fowler and Knauer, 1986; Alldredge and Silver, 1988; Alldredge and Gotschalk, 1989). Microscopic observations reveal that most of the faecal-aggregates were composed of smaller particles with distinct cylindrical and ovoid shapes resembling individual faecal pellets, or at least tightly packed and optically opaque sub-units similar to those detected by Alldredge and Gotschalk (1990). However, within this particle type a large variety of shapes and forms occurred (Figs. 4 and 5): some were relatively compact and consisted of agglomerated faecal pellets, while others contained less distinct material, such as loose faecal matter, phyto detritus, or feeding structures or exopolymeric polysaccharide particles. Our observations are very similar to particles collected from the PFZ south of New Zealand using large volume in-situ filtration system (MULVFS) by Lam and Bishop (2007), who found intact faecal pellets as well as aggregates of faecal matter and marine snow. They concluded that the material was heavily processed by zooplankton-a view which we share based on our observations of large numbers of aggregates containing at least some faecal matter. Wexels Riser et al. (2008) studied the vertical flux regulation by zooplankton in the northern Barents Sea, where the importance of faecal pellets in terms of carbon flux below the euphotic layer was decreasing. They proposed that faecal pellets were transferred into unidentifiable organic matter that is to a large extent faecal pellet derived-which resembles our faecal-aggregates. Since the particles of this class vary a lot, their origin might be due to several different formation pathways. In addition to direct faecal material production as a result of grazing, it is likely that the sinking material underwent other processes, such as fragmentation of particles into smaller ones (Noji et al., 1991; Dilling and Alldredge, 2000). According to Dilling and Alldredge (2000) large zooplankton such as euphausiids are capable of fragmenting marine snow and Noji et al. (1991) observed copepods breaking up faecal pellets. This could explain some of the large size range and variety in shapes within the faecalaggregates. Unfortunately, zooplankton data from SAZ-Sense are not available for comparison. But the faecal pellets as preserved in the gels and divided into cylindrical and ovoid pellets provide some indication of probable taxa (Fig. 3). The cylindrical faecal pellets were probably derived from copepods and euphausiids, and the ovoid faecal pellets may originate from small copepods or larvaceans (Gonzalez, 1992; Turner, 2002; Wilson et al., 2008; Wexels Riser et al., 2008).

Phyto-cells were most important at the diatom dominated PFZ site P2 (Tables 6 and 7), where they were collected as chains and rarely also as individual cells (Fig. 6). These highly silicified diatom species (e.g. Fragilariopsis kerguelensis; de Salas et al., 2011) might have entered the gel trap individually, or within aggregates which then fell apart in the traps. Since diatom aggregates have been collected in previous studies (e.g. Waite and Nodder, 2001; Waite et al., 2005), it is quite possible that our phyto-cells reached the traps within fluff- or faecal-aggregates. Indeed, our images of PFZ particles (Fig. 5) were very similar to those of Waite et al. (2005) for aggregates in the SAZ east of New Zealand.

\subsection{Ecosystem controls on the flux}

\subsubsection{Influence of particle types on vertical export}

Gross primary production (GPP) and net primary production (NPP) at P1 were about twice as high as at P3 and three times higher than at P2 (Table 1). At P1 and P2 POC fluxes were approximately one magnitude lower than GPP, and at P3 almost two magnitudes. Considering these variations among all three sites implies that primary production and carbon flux were not coupled in a linear way (Table 1). This is consistent with the perspective developed in earlier work. Boyd and Newton (1995, 1999) suggested that details of ecosystem structure are as influential as primary production in the control of export. The particles identified in the gel traps make clear that zooplankton were an important regulator of export throughout the study region, contributing strongly to the flux either as faecal pellets or faecal-aggregates (Figs. 4 and 5). This is in agreement with the estimated high importance of grazing from shipboard incubation experiments which suggested that, in the eastern and western SAZ, grazing removed on average 67 and $82 \%$ of the primary production, respectively (Pearce et al., 2011). The smaller and more compact faecal-aggregates at $\mathrm{P} 2$ and $\mathrm{P} 3$, in comparison to the larger and fluffier faecal-aggregates at P1 (Table 8, Fig. 5), suggests that the impact of grazing is more pronounced in the eastern SAZ and the PFZ. This is supported by the relatively large contribution of faecal pellets to the flux in the eastern SAZ (Table 7). In contrast, the higher abundance of fluff-aggregates and the somewhat looser appearance of the faecal-aggregates in the western SAZ suggest the possible importance of different processes in the water column, e.g. coagulation of phytoplankton and formation of phyto-detritus. Nevertheless, hardly any unprocessed phytoplankton material was found in the traps (Figs. 4 and 5). This in part probably reflects the distance between the biomass distributions in shallow mixed layers and the traps (Fig. 2, Table 9), and emphasises the point that we measured mesopelagic fluxes (compare also Section 4.2.2), for which considerable degradation had 
Table 9

Comparison of POC fluxes and e-ratios.

\begin{tabular}{|c|c|c|c|c|c|c|c|c|c|c|c|}
\hline \multirow[t]{3}{*}{ Site i.d. } & \multicolumn{3}{|c|}{ PPS3/3 trap } & \multicolumn{3}{|c|}{ IRS trap } & \multirow{3}{*}{$\begin{array}{l}\text { Gel trap } \\
\text { Depth } \\
\text { m }\end{array}$} & \multicolumn{2}{|c|}{ Ebersbach et al. algorithm } & \multirow{3}{*}{$\begin{array}{l}\text { Guidi et al. } \\
\text { algorithm } \\
\text { POC flux } \\
\text { mmolC m } \\
\end{array}$} & \multirow{3}{*}{$\begin{array}{l}\text { Ebersbach:Guid } \\
\text { POC flux } \\
\text { ratio }\end{array}$} \\
\hline & \multirow{2}{*}{$\begin{array}{l}\text { Depth } \\
\text { m }\end{array}$} & \multicolumn{2}{|l|}{ POC flux } & \multirow{2}{*}{$\begin{array}{l}\text { Depth } \\
\text { m }\end{array}$} & \multicolumn{2}{|l|}{ POC flux } & & \multicolumn{2}{|l|}{ POC flux } & & \\
\hline & & mmolC $\mathbf{m}^{-2} \mathbf{d}^{-1}$ & e-Ratio & & $\operatorname{mmolC} \mathbf{m}^{-2} \mathbf{d}^{-1}$ & e-Ratio & & $\operatorname{mmolC} \mathrm{m}^{-2} \mathbf{d}^{-1}$ & e-Ratio & & \\
\hline \multirow[t]{4}{*}{ P1 } & 150 & $3.3 \pm 1.8$ & $0.04 \pm 0.04$ & - & - & - & 140 & 6.1 & 0.09 & 5.1 & 1.2 \\
\hline & & & & - & - & - & 190 & 10.3 & 0.16 & 8.7 & 1.2 \\
\hline & & & & & & & 240 & 10.6 & 0.16 & 6.3 & 1.7 \\
\hline & & & & & & & 290 & 8.1 & 0.12 & 4.9 & 1.6 \\
\hline \multirow[t]{4}{*}{ P2 } & 150 & $2.1 \pm 0.9$ & $0.06 \pm 0.04$ & 170 & 1.8 & 0.05 & 140 & 9.5 & 0.27 & 7.2 & 1.3 \\
\hline & & & & 320 & 1.1 & 0.03 & 190 & 5.9 & 0.17 & 5.3 & 1.1 \\
\hline & & & & & & & 240 & 5.6 & 0.16 & 4.7 & 1.2 \\
\hline & & & & & & & 290 & 5.2 & 0.15 & 4.6 & 1.1 \\
\hline \multirow[t]{4}{*}{ P3 } & 150 & $0.9 \pm 0.4$ & $0.01 \pm 0.1$ & 170 & 0.9 & 0.02 & 140 & 0.8 & 0.02 & 1.4 & 0.6 \\
\hline & & & & 320 & 0.2 & 0.00 & 190 & 1 & 0.02 & 1.2 & 0.9 \\
\hline & & & & & & & 240 & 0.6 & 0.01 & 1.2 & 0.5 \\
\hline & & & & & & & 290 & 0.6 & 0.01 & 0.8 & 0.8 \\
\hline
\end{tabular}

1. e-Ratio=POC flux/GPP (GPP in Table 1; data from Cavagna et al., 2011)

2. See Section 2 for discussion of algorithms for POC content of particles.

already occurred during the transit out of the mixed layer and into the traps.

\subsubsection{Impact of particle sizes and structure on sinking rates and export}

According to Stokes law for spherical particle settling $\left(w_{s}=\left(g \Delta \rho d^{2}\right) /(18 \eta)\right)$, the settling velocity, $w_{s}$, is proportional to excess density above seawater, $\Delta \rho$, to the square of the particle size, $d$, and inversely proportional to the viscosity of the surrounding seawater, $\eta$. Particle size presumably influenced individual particle sinking rates, because particle size varied more than an order of magnitude (Fig. 7), although median particle size varied by less than $50 \%$ among the sites (Table 8 ) so that the influence of size on total flux may not have been particularly strong. Particle excess density (partly controlled by porosity) may have been more important than size in terms of sinking rates, and thus in terms of degradation prior to reaching the traps, given the variations between tightly packed and more fluffy or amorphous faecal-aggregates (Figs. 4 and 5). This may have contributed to the high flux attenuation with depth that was found at P2. Regarding the ballasting effect, the presence of calcium carbonate and silica minerals have been demonstrated to influence POC export to traps in the ocean interior (Armstrong et al., 2002; Francois et al., 2002; Klaas and Archer, 2002), although their role may be less relevant closer to the ocean surface (Passow, 2004; Trull et al., 2008). Therefore, the highest $\mathrm{CaCO}_{3}$ flux at $\mathrm{P} 1$ might have enhanced export as previously suggested for this region (Cardinal et al., 2005).

Biogenic silica only played a role at P2 (Table 3 ) and indicates the importance of diatoms for the export in the PFZ. However, the evenly distributed BSi content over particles sinking at different rates as obtained from the IRS trap (Table 4) does not support the view that the mineral had the dominant impact on settling rates of the sinking material. This would agree with the finding that the slow sinking and the fast sinking fraction at P2 (see Section 3.1.2 and Table 4) appear to be composed of similar chemical composition as far as POC and BSi are concerned. In general, POC/BSi ratios show no clear trend as a function of sinking rate across all the fractions. This suggests that sinking rates did not depend strongly on mineral ballast contents (this perspective is likely to extend to all mineral contents, given that PIC contents at P2 were very low, less than $10 \%$ of BSi contents (Table 3 ) and based on historical data (Trull et al., 2001b), lithogenic fluxes at this site were probably also very low). However, material without BSi, may have sunk extremely slowly. This is consistent with the very high $\mathrm{POC} / \mathrm{BSi}$ ratios in cup 11 for the fraction sinking at less than $2.3 \mathrm{~m} \mathrm{~d}^{-1}$ in the IRS traps (Table 4).

The PFZ site P2 also shows the strongest attenuation with depth (Table 9). This might result from the high abundance of small particles (Table 8, Figs. 4 and 5) that could possibly be too small to sink, as generally for the same particle type sinking rates decrease with decreasing particle size (Alldredge and Gotschalk, 1988; Ploug et al., 2008). Therefore both phyto-cells and tiny faecal-aggregates could contribute to the slow sinking fraction $\left(2.3-6 \mathrm{~m} \mathrm{~d}^{-1}\right.$ ) as collected in the IRS trap (Table 4). The fast sinking fraction (410-850 $\left.\mathrm{m} \mathrm{d}^{-1}\right)$ may contain larger faecal-aggregates and/or faecal pellets.

BSi export was high in the PFZ (P2), but low in the SAZ (P1 and P3). In agreement with literature (e.g. Cardinal et al., 2005), fluxes of BSi and POC were strongly decoupled at P2, and thus POC to biomineral ratios were high in the SAZ and low in the PFZ. Based on the findings of many empty diatoms in the gels (mainly F. kerguelensis, Fig. 5), this might be a mechanism for the downwards transport of silicate at this site.

\subsubsection{Estimates of export efficiency}

Export-ratios (e-ratios; e-ratio=POC/NPP (Table 9) based on NPP from Cavagna et al. (2011)) and POC as collected in the traps (Tables 3, 4, and 7) were generally low: on average $0.13,0.19$, and 0.02 at P1, P2, and P3, respectively (Table 9). Sequence and magnitudes coincide with the e-ratio calculations based on export production estimated from ${ }^{234} \mathrm{Th}$ water column inventories from Jacquet et al. (2011), who concluded that low export efficiency in the more productive eastern SAZ (P3) - in contrast to the higher export in the less productive western SAZ (P1) - was somewhat unexpected. The high e-ratios at P2 may mirror the higher export efficiency due to the post bloom situation or the impact of large diatoms on carbon flux as suggested by Boyd and Newton (1995). The observation that export at P3 was least efficient despite highest primary production (Table 9 ) coincides with relatively small faecalaggregates (Figs. 4 and 5, Table 8) and low ballast mineral content, suggesting that slow sinking may have influenced export flux. The distance between the shallow mixed layers, where biomass production and export occurred, and the deeper mesopelagic traps influences our ability to assign the cause of the variations in the 
trap-based e-ratios among the sites. In particular, the greater distance at P3 than at P1 and P2 (Fig. 2) may have contributed to its lower apparent e-ratio.

Because export efficiency may of course vary seasonally (Wassmann, 1990; Honjo, 1996), it is important to take the seasonal context of the study into account. According to Mongin et al. (2011), the bloom in the western SAZ (P1) had not reached its peak. The large amount of relatively unprocessed and fresh material at P1 (see Section 4.4.1, Figs. 4 and 5), supports the idea that we encountered a growing bloom. In the eastern SAZ (P3) the blooming event occurred over a longer time period without a distinct peak prior to the cruise, and in the PFZ (P2) the peak biomass period had already passed (Mongin et al., 2011). This is in agreement with the more compact (and more processed) particles at these sites (P2 and P3) if we assume that phytoplankton has been grazed down and zooplankton mediated particles were produced. The large number of empty diatoms in the gel traps at the P2 site (Fig. 5, Table 6) could be a result of bloom senescence at the sampling time.

Recently, the term high biomass, low export condition (HBLE) has been suggested for settings like we found at P1 (Lam and Bishop, 2007). According to these authors the most important factors determining POC export during the Southern Ocean Iron Experiment (SOFeX) were biological processes that affected the fragmentation and remineralisation of large particles-coinciding with the view that faecal-aggregates usually are the main contributors to POC flux as previous studies have indicated (e.g. Bishop et al., 1977, 1987). This is in agreement with the dominance of more or less heavily processed particles (faecalaggregates) during SAZ-Sense and also agrees with many other studies in Polar regions (e.g. Blain et al., 2007; Pollard et al., 2007; Wassmann et al., 2008).

The results of the project 'Carbon flux and ecosystem feed back in the northern Barents Sea in an era of climate change' (CABANERA; Wassmann et al., 2008) indicate that vertical carbon export was mainly driven by grazing and pelagic retention (Reigstad et al., 2008) and the production of fast sinking faecal pellets (Wexels Riser et al., 2008). This coincides with results from the Kerguelen Ocean and Plateau compared Study (KEOPS) that was carried out in PFZ waters (Blain et al., 2007), where most of the particle flux originated from faecal matter (Ebersbach and Trull, 2008). Similar to our dominating faecal-aggregates, KEOPS reported on aggregates of faecal matter that were responsible for downward POC export. A comparison of flux spectra from SAZ-Sense (Fig. 6) and KEOPS (Ebersbach and Trull, 2008) validates this. Compared with particle distribution during KEOPS, the PFZ site P2 shows a slight shift towards smaller particles. The SAZ sites differ somewhat from each other: at P3 the range of particle sizes lies in the average distribution found during KEOPS, but large particles are not present at all, and at P1 the trend is somewhat shifted towards larger particles. Overall, the generally similar characteristics at KEOPS and SAZ-Sense indicate similar export mechanisms.

In contrast, POC export during the Southern Ocean Iron Release Experiment SOIREE, that took place under similar conditions (HNLC and iron fertilised waters; Boyd et al., 2000) was driven by phyto-detrital aggregates (Waite and Nodder, 2001). Jackson et al. (2005) compared measured particle fluxes from SOIREE with model estimates and yielded number flux spectra, which resemble our particle distribution in regard to overall trends. However, the SOIREE particles in total were much smaller (as small as $0.8 \mu \mathrm{m}$ in diameter), the abundance of the $10 \mu \mathrm{m}$ sized particles (our smallest) was about one magnitude higher and the decrease towards larger particles was less steep (for the $0.4 \mathrm{~cm}$ size class the difference exceeds two magnitudes), suggesting that during SOIREE the flux was carried by larger particles.
This agrees with the dominance of large marine-snow aggregates entirely composed of diatoms observed in SOIREE gels (Waite and Nodder, 2001) and is in opposite to the more tightly packed faecal-aggregates responsible for POC flux during SAZ-Sense. Marine-snow aggregates have also been observed in many other studies, where aggregation of phytoplankton was pre-dominant (e.g. Alldredge and Gotschalk, 1989; Passow et al., 1994; Waite et al., 2005; Pollard et al., 2007; Salter et al., 2007). The CROZet natural iron bloom and EXport experiment (CROZEX), for instance, also suggests an important role for the direct export of a diverse range of diatoms (Salter et al., 2007).

Thus, the different export mechanisms and the subsequently different particle regimes highlight the importance of studying flux composition in detail. As shown by various studies on particle size distribution in different regions of the ocean (e.g. Jackson et al., 2005; Ebersbach and Trull, 2008; Guidi et al., 2008; Stemmann et al., 2008; Jouandet et al., 2011), the approach of determining particle size spectra provides insights in the context of carbon transport from the surface ocean into the mesopelagic zone. This is an important step towards prediction of carbon flux in response to changing environments.

\section{Conclusions}

The overall results are a clear reminder that simple indices, such as satellite estimates of phytoplankton biomass, are a poor guide to ecosystem function in general, or to export production specifically. The elevated biomass observed at P3, which is present throughout the year as indicated by satellite remote sensing (Mongin et al., 2011), was not accompanied by elevated primary or new production, and did not translate into increased sinking flux, at least not during the short shipboard observational period reported here. This provides a cautionary note, as have other studies of natural iron fertilisation (Blain et al., 2007; Pollard et al., 2007), about the effectiveness of iron inputs (which were elevated at the P3 site; Bowie et al., 2009) to increase biological pump strength. The clear influence of zooplankton grazing in the control of particle production and export observed via the use of the polyacrylamide gel traps emphasises the influence of higher trophic levels on biological pump responses to stimulation of photosynthesis. This perspective, known as the ecumenical iron hypothesis, considers the impact of grazers on primary production in iron-limited ecosystems (Morel et al., 1991; Cullen, 1995). It was originally formulated based on general ecological principles, and has less commonly been directly demonstrated. The combination of three trap types to obtain geochemical flux measurements, particle sinking rate estimates, and images of intact particles is powerful and will benefit other studies in the future.

\section{Acknowledgments}

This research was in part supported by the Australian Government Cooperative Research Centres Programme through the Antarctic Climate and Ecosystems CRC (ACE CRC), Australian Antarctic Science projects \#2720 and \#1156, the Australian Antarctic Division, CSIRO Marine and Atmospheric Research, and the captain and crew of R.S.V. Aurora Australis. The NERC Earth Observation Data Acquisition and Analysis Service (NEODAAS) supplied data for the ocean colour image provided by the Plymouth Marine Laboratory. The Institute National des Sciences de l'Univers (INSU, France) provided the PPS3/3 trap, and F. Dehair (Vrije Universiteit Brussel, Belgium) provided one IRS trap. Thanks to D. Mclaughlin (moorings preparation), C. Moy (gel preparation), M. Rosenberg (assistance 
with trap deployments), C. Bloomfield (biogenic silica analysis), and T. Rodemann (UTAS Central Science Laboratory, elemental analysis). U. Passow, U. Bathmann, E. Nöthig, C. Klaas, D. Wolf-Gladrow and B. Griffiths are thanked for thoughtful discussions, as are two anonymous reviewers who helped to improve the manuscript. F. Ebersbach was funded by GLOMAR (Ph.D. scholarship).

\section{References}

Alldredge, A.L., 1998. The carbon, nitrogen and mass content of marine snow as a function of aggregate size. Deep-Sea Research I 45, 529-541.

Alldredge, A.L., Gotschalk, C., 1988. In situ settling behaviour of marine snow Limnology and Oceanography 33, 330-351.

Alldredge, A.L., Gotschalk, C., 1989. Direct observations of the mass flocculation of diatom blooms: characteristics, settling velocities and formation of diatom aggregates. Deep-Sea Research 36, 159-171.

Alldredge, A.L., Gotschalk, C., 1990. The relative contribution of marine snow of different origins to biological processes in coastal waters. Continental Shelf Research 10, 41-58.

Alldredge, A.L., Jackson, G.A., 1995. Aggregation in marine systems. Deep-Sea Research II 42, 1-7.

Alldredge, A.L., Silver, M.W., 1988. Characteristics, dynamics and significance of marine snow. Progress in Oceanography 20, 41-82.

Armstrong, R.A., Lee, C., Hedges, J.I., Honjo, S., Wakeham, S.G., 2002. A new, mechanical model for organic carbon fluxes in the ocean based on the quantitative association of POC with ballast minerals. Deep-Sea Research II 49, 219-236.

Armstrong, R.A., Peterson, M.L., Lee, C., Wakeham, S.G., 2009. Settling velocity spectra and the ballast ratio hypothesis. Deep-Sea Research II 56, 1470-1478.

Azam, F., 1998. Oceanography: microbial control of carbon flux: the plot thickens. Science 280, 694-696.

Bishop, J.K.B., 1989. Regional extremes in particulate matter composition and flux: effects on the chemistry of the ocean interior. In: Berger, W.H., Smetacek, V., Wefer, G. (Eds.), Dahlem Workshop Life Science Report-Productivity of the Oceans: Present and Past. John Wiley and Sons, New York, pp. 117-138.

Bishop, J.K.B., Edmond, J.M., Ketten, D.R., Bacon, M.P., Silker, W.B., 1977. The chemistry, biology, and vertical flux of particulate matter from the upper $400 \mathrm{~m}$ of the equatorial Atlantic Ocean. Deep-Sea Research 24, 511-548.

Bishop, J.K.B., Stepien, J.C., Wiebe, P.H., 1987. Particulate matter distributions, chemistry and flux in the Panama basin: response to environment forcing. Progress in Oceanography 17, 1-59.

Blain, S., Quéguiner, B., Armand, L., Belviso, S., Bombled, B., Bopp, L., Bowie, A Brunet, C., Brussaard, C., Carlotti, F., Christaki, U., Corbiere, A., Durand, I. Ebersbach, F., Fuda, J.-L., Garcia, N., Gerringa, L., Griffiths, B., Guige, C., Guillerm, C., Jacquet, S.H.M., Jeandel, C., Laan, P., Lefevre, D., Lo Monaco, C. Malits, A., Mosseri, J., Obernosterer, I., Park, Y.-H., Picheral, M., Pondaven, P., Remenyi, T., Sandroni, V., Sarthou, G., Savoye, N., Scouarnec, L., Souhaut, M. Thuiller, D., Timmermans, K., Trull, T., Uitz, J., van Beek, P., Veldhuis, M. Vincent, D., Viollier, E., Vong, L., Wagener, T., 2007. Effect of natural iron fertilization on carbon sequestration in the Southern Ocean. Nature 446 1070-1075.

Bowie, A.R., Lannuzel, D., Remenyi, T.A., Wagener, T., Lam, P.J., Boyd, P.W., Guieu, C., Townsend, A.T., Trull, T.W., 2009. Biogeochemical iron budgets of the Southern Ocean south of Australia demonstrate that summertime supply decouples iron and nutrient cycles in the subantarctic zone. Global Biogeochemical Cycles 23, GB4034. doi:10.1029/2009GB003500.

Bowie, A.R., Griffiths, F.B., Dehairs, F., Trull, T., 2011. Oceanography of the subantarctic and polar frontal zones south of Australia during summer: setting of the SAZ-Sense study. Deep-Sea Research II 58, 2059-2070.

Boyd, P., Newton, P., 1995. Evidence of the potential influence of planktonic community structure on the interannual variability of particulate organic carbon flux. Deep-Sea Research I 42, 619-639.

Boyd, P.W., Newton, P.P., 1999. Does planktonic community structure determine downward particulate organic carbon flux in different oceanic provinces? Deep-Sea Research I 46, 63-91.

Boyd, P.W., Trull, T.W., 2007. Understanding the export of biogenic particles in oceanic waters: is there consensus? Progress in Oceanography 72, 276-312.

Boyd, P.W., Watson, A.J., Law, C.S., Abraham, E.R., Trull, T., Murdoch, R., Bakker, D.C.E., Bowie, A.R., Buesseler, K.O., Chang, H., Charette, M., Croot, P., Downing, K., Frew, R., Gall, M., Hadfield, M., Hall, J., Harvey, M., Jameson, G., LaRoche, J., Liddicoat, M., Ling, R., Maldonado, M.T., McKay, R.M., Nodder, S., Pickmere, S., Pridmore, R., Rintoul, S., Safi, K., Sutton, P., Strzepek, R., Tanneberger, K., Turner, S., Waite, A., Zeldis, J., 2000. A mesoscale phytoplankton bloom in the polar Southern Ocean stimulated by iron fertilization. Nature 407, 695-702.

Buesseler, K.O., 1991. Do upper-ocean sediment traps provide an accurate record of particle flux? Nature 353, 420-423.

Buesseler, K.O., Boyd, P.W., 2009. Shedding light on processes that control particle export and flux attenuation in the twilight zone of the open ocean. Limnology and Oceanography 54, 1210-1232.

Buesseler, K.O., Lamborg, C., Boyd, P.W., Lam, P.J., Trull, T.W., Bidigare, R.R., Bishop, J.K.B., Casciotti, K.L., Dehairs, F., Elskens, M., Honda, M., Karl, D.M., Siegel, D.A. Silver, M.W., Steinberg, D.K., Valdes, J., Van Mooy, B., Wilson, S., 2007a.
Revisiting carbon flux through the ocean's twilight zone. Science 316, 567-570.

Buesseler, K.O., Antia, A.V., Chen, M., Fowler, S.W., Gardner, W.D., Gustafsson, O., Harada, K., Michaels, A.F., van der Loef, M.R., Sarin, M., Steinberg, D.K., Trull, T., $2007 \mathrm{~b}$. An assessment of the use of sediment traps for estimating upper ocean particle fluxes. Journal of Marine Research 65, 345-416.

Cardinal, D., Savoye, N., Trull, T.W., Andre, L., Kopczynska, E.E., Dehairs, F., 2005. Variations of carbon remineralisation in the Southern Ocean illustrated by the $\mathrm{Ba}_{\mathrm{xs}}$ proxy. Deep-Sea Research I 52, 355-370.

Cassar, N., DiFiore, P., Barnett, B.A., Bender, M.L., Bowie, A.R., Tilbrook, B., Petrou, K., Westwood, K.J., Wright, S.W., Lefevre, D., 2011. The influence of iron and light on net community production in the Subantarctic and Polar Frontal Zones. Biogeosciences 7, 5649-5674.

Cavagna, A.-J., Elskens, M., Griffiths, F.B., Fripiat, F., Jacquet, S.H.W., Westwood, K.J., Dehairs, F., 2011. Contrasting regimes of production and potential for carbon export in the Sub-Antarctic and Polar Frontal Zones south of Tasmania. DeepSea Research II 58, 2235-2247.

Cheah, W., McMinn, A., Griffiths, F.B., Westwood, K., Webb, J., Molina, E., Wright, S.W. van den Enden, R, 2011. Assessing Sub-Antarctic Zone primary productivity from fast repetition rate fluorometry. Deep-Sea Research II 58, 2179-2188.

Cullen, J.J., 1995. Status of the iron hypothesis after the Open-Ocean Enrichment Experiment. Limnology and Oceanography 40, 1336-1343.

De La Rocha, C., Passow, U., 2007. Factors influencing the sinking of POC and the efficiency of the biological carbon pump. Deep-Sea Research II 54, 639-658.

de Salas, M.F., Eriksen, R., Davidson, A.T., Wright, S., 2011. Protistan communities in the Australian sector of the subantarctic zone during SAZ-Sense. Deep-Sea Research II 58, 2135-2149.

Dilling, L., Alldredge, A.L., 2000. Fragmentation of marine snow by swimming macrozooplankton: a new process impacting carbon cycling in the sea. DeepSea Research I 47, 1227-1245.

Doblin, M.A., Ralph, P.J., Petrou, K.L., Shelly, K., Westwood, K., van den Enden, R., Wright, S.W., Griffiths, F.B., 2011. Diel variation of chl-a fluorescence, phytoplankton pigments and productivity in the Sub-Antarctic Zone. Deep-Sea Research II 58, 2189-2199.

Ebersbach, F., Trull, T., 2008. Sinking particle properties from polyacrylamide gels during the KErguelen Ocean and Plateau compared Study (KEOPS): zooplankton control of carbon export in an area of persistent natural iron inputs in the Southern Ocean. Limnology and Oceanography 53, 212-224.

Evans, C., Thomson, P.G., Davidson, A.T., Bowie, A.R., van den Enden, R., Witte, H. Brussaard, C.P.D., 2011. Potential implications of climate change-induced shifts in microbial distribution for carbon cycling in the Australian Southern Ocean. Deep-Sea Research II 58, 2150-2161.

Falkowski, P.G., Scholes, R.J., Boyle, E.A., Canadell, J., Canfield, D., Elser, J., Gruber, N., Hibbard, K., Hogberg, P., Linder, S., Mackenzie, F.T., Moore, B.I., Pedersen, T., Rosenthal, Y., Seitzinger, S., Smetacek, V., Steffen, W., 2000. The global carbon cycle: a test of our knowledge of earth as a system. Science 290, 291-296.

Fowler, S.W., Knauer, G.A., 1986. Role of large particles in the transport of elements and organic compounds through the oceanic water column. Progress in Oceanography 16, 147-194.

Francois, R., Honjo, S., Krishfield, R., Manganini, S., 2002. Factors controlling the flux of the organic carbon to the bathypelagic zone of the ocean. Global Biogeochemical Cycles 16 (1087), 34 1-34 20. doi:10.1029/2001GB001722.

Gonzalez, H.E., 1992. The distribution and abundance of krill faecal material and oval pellets in the Scotia and Weddell Seas (Antarctica) and their role in particulate flux. Polar Biology 12, 81-91.

Gonzalez, H.E., Smetacek, V., 1994. The possible role of the cyclopoid copepod Oithona in retarding vertical flux of zooplankton faecal material. Marine Ecology-Progress Series 113, 233-246.

Guidi, L., Jackson, G.A., Stemmann, L., Carlos Miquel, J., Picheral, M., Gorsky, G., 2008. Relationship between particle size distribution and flux in the mesopelagic zone. Deep-Sea Research I 55, 1364-1374.

Gust, G., Kozerski, H.-P., 2000. In situ sinking-particle flux from collection rates of cylindrical traps. Marine Ecology-Progress Series 208, 93-106.

Hill, K.S., Rintoul, S.R., Coleman, R., Ridgeway, K.R., 2008. Wind forced low frequency variability of the East Australia Current. Geophysical Research Letters 35 (L08602). doi:10.1029/2007GL032912.

Honjo, S., 1996. Fluxes of particles to the interior of the open ocean. In: Ittekkot, V., Aschauffer, P., Honjo, S., Depetris, P. (Eds.), Particle Flux in the Oceans. SCOPE 57. Wileys, New York, pp. 91-154.

Jackson, G.A., Waite, A.M., Boyd, P.W., 2005. Role of algal aggregation in vertical carbon export during SOIREE and in other low biomass environments. Geophysical Research Letters 32 (L13507), 1-4. doi:10.1029/2005GL023180.

Jacquet, S.H.M., Lam, P., Trull, T., Buesseler, K., Dehairs, F., 2011. Carbon export production in the Polar Front Zone and Subantarctic Zone south of Tasmania. Deep-Sea Research II 58, 2277-2292.

Jouandet, M.-P., Trull, T.W., Picharel, M., Guidi, L., Ebersbach, F., Stemmann, L. Blain, S., 2011. Optical imaging of mesopelagic particles indicated deep carbon flux beneath a natural iron fertilized bloom in the Southern Ocean, Limnology and Oceanography 56, 1130-1140. doi:10.4319/lo.2011.56.3.1130.

Klaas, C., Archer, D.E., 2002. Association of sinking organic matter with various types of mineral ballast in the deep sea: implication for the rain ratio. Global Biogeochemical Cycles 16 (1116), 63 1-63 14. doi:10.1029/2001GB001765.

Kwon, E.Y., Primeau, F., Sarmiento, J.L., 2009. The impact of remineralization depth on the air-sea carbon balance. Nature Geoscience 2, 630-635. 
Lam, P.J., Bishop, J.K.B., 2007. High biomass, low export regimes in the Southern Ocean. Deep-Sea Research II 54, 601-638.

Lampitt, R.S., Antia, A.N., 1997. Particle flux in the deep seas: regional characteristics and temporal variability. Deep-Sea Research I 44, 1377-1403.

Lannuzel, D., Remenyi, T., Lam, P.J., Townsend, A., Ibisanmi, E., Butler, E., Wagener, T., Schoemann, V., Bowie, A.R., 2011. Distribution of dissolved and particulate iron in the sub-Antarctic and Polar Frontal Southern Ocean (Australian sector). Deep-Sea Research II 58, 2094-2112.

Lutz, M., Dunbar, R., Caldeira, K., 2002. Regional variability in the vertical flux of particulate organic carbon in the ocean interior. Global Biogeochemical Cycles 16 (1037), 11 11-11 18. doi:10.1029/2000GB001383.

Lutz, M.J., Caldeira, K., Dunbar, R.B., Behrenfeld, M.J., 2007. Seasonal rhythms of net primary production and particulate organic carbon flux to depth describe the efficiency of biological pump in the global ocean. Journal of Geophysical Research 112 (C10011), 1-26. doi:10.1029/2006JC003706.

Martin, J.H., Knauer, G.A., Karl, D.M., Broenkow, W.W., 1987. VERTEX: carbon cycling in the northeast Pacific. Deep-Sea Research 34, 267-285.

Matear, R., Hirst, A.C., 1999. Climate change feedback on the future oceanic $\mathrm{CO}_{2}$ uptake. Tellus 51, 722-733.

Menden-Deuer, S., Lessard, E.J., 2000. Carbon to volume relationship for dinoflagellates, diatoms, and other protist plankton. Limnology and Oceanography 45, 569-579.

Michaels, A.F., Silver, M.W., 1988. Primary production, sinking fluxes and the microbial food web. Deep-Sea Research A 35, 473-490.

Mongin, M., Matear, R., Chamberlain, M., 2011. Seasonal and spatial variability of remotely sensed chlorophyll and physical fields in the SAZ-Sense region. Deep-Sea Research II 58, 2082-2093.

Morel, F.M.M., Rueter, J.G., Price, N.M., 1991. Iron nutrition of phytoplankton and its possible importance in the ecology of ocean regions with high nutrients and low biomass. Oceanography 4, 56-61.

Noji, T.T., Estep, K.W., MacIntyre, F., Norrrbin, F., 1991. Image analysis of faecal material grazed upon by three species of copepods: evidence for coprorhexy, coprophagy, and coprochaly. Journal of the Marine Biological Association of the United Kingdom 71, 465-480.

Passow, U., 2004. Switching perspectives: do mineral fluxes determine particulate organic carbon or vice versa? Geochemistry Geophysics Geosystems 5, 1-5. doi:10.1029/2003GC000670.

Passow, U., Alldredge, A.L., Logan, B.E., 1994. The role of particulate carbohydrate exudates in the floccolation of diatom blooms. Deep-Sea Research I 42, 335-357.

Pearce, I., Davidson, A., Thomson, P., Wright, S., van den Enden, R., 2011. Marine microbial ecology in the Subantarctic Zone: rates of bacterial and phytoplankton growth and grazing by heterotrophic protists. Deep-Sea Research II 58, 2248-2259.

Peterson, M.L., Wakeham, S.G., Lee, C., Askea, M.A., Miquel, J.C., 2005. Novel techniques for collection of sinking particles in the ocean and determining their settling rates. Limnology and Oceanography Methods 3, 520-532.

Peterson, M.L., Fabres, J., Wakeham, S.G., Lee, C., Miquel, J.C., 2009. Sampling the vertical particle flux in the upper water column using a large diameter free-drifting Net-Trap adapted to an Indented Rotating Sphere sediment trap. Deep-Sea Research II 56, 1547-1557.

Petrou, K., Hassler, C.S., Doblin, M.A., Shelly, K., Schoemann, V., van den Enden, R. Wright, S.W., Ralph, P.J., 2011. Iron limitation and high light stress on phytoplankton populations from the Australian sub-Antarctic zone (SAZ) Deep-Sea Research II 58, 2200-2211.

Ploug, H., Iversen, M.H., Fischer, G., 2008. Ballast, sinking velocity, and apparent diffusivity within marine snow and zooplankton fecal pellets: implications for substrate turnover by attached bacteria. Limnology and Oceanography 52 , 1878-1886.

Pollard, R., Sanders, R., Lucas, M., Statham, P., 2007. The Crozet Natural Iron Bloom and Export Experiment (CROZEX). Deep-Sea Research II 54, 1905-1914.

Reigstad, M., Wexel Riser, C., Wassmann, P., Ratkova, T., 2008. Vertical export of particulate organic carbon: attenuation, composition and loss rates in the northern Barents Sea. Deep-Sea Research II 55, 2308-2319.
Rintoul, S., Trull, T.W., 2001. Seasonal evolution of the mixed layer in the Subantarctic Zone south of Australia. Journal of Geophysical Research 106 (C12), 31 447-31 462. doi:10.1029/2000JC000329.

Salter, I., Lampitt, R.S., Sanders, S., Poulton, A.J., Kemp, A.E.S., Boorman, B., Saw, K. Pearce, R., 2007. Estimating carbon, silica and diatom export from a naturally fertilised phytoplankton bloom in the Southern Ocean using PELAGRA: a novel drifting sediment trap. Deep-Sea Research II 54, 2223-2259.

Sarmiento, J.L., Le Quéré, C., 1996. Oceanic Carbon Dioxide Uptake in a Model of Century-Scale Global Warming. Science 274, 1346-1350.

Sedwick, P.N., DiTullio, G.R., Hutchins, D.A., Boyd, P.W., Griffiths, B.F., Crossley, A.C., Trull, T.W., Quéguiner, B., 1999. Limitation of algal growth by iron deficiency in the Australian Subantarctic region. Geophysical Research Letters 26, 2865-2868. doi:10.1029/1998GL002284.

Sedwick, P.N., Bowie, A., Trull, T.W., 2008. Dissolved iron in the Australian sector of the Southern Ocean (CLIVAR SR3 section): meridional and seasonal trends. Deep-Sea Research I 55, 911-925.

Stemmann, L., Jackson, G.A., Ianson, D., 2004. A vertical model of particle size distributions and fluxes in the midwater column that includes biological and physical processes-Part I: model formulation. Deep-Sea Research I 51 865-884.

Stemmann, L., Eloire, D., Sciandra, A., Jackson, G.A., Guidi, L., Picheral, M., Gorsky G., 2008. Volume distribution for particles between 3.5 and $2000 \mu \mathrm{m}$ in the upper $200 \mathrm{~m}$ region of the South Pacific Gyre. Biogeosciences 5, 299-310.

Turner, J.T., 2002. Zooplankton fecal pellets, marine snow and sinking phytoplankton blooms. Aquatic Microbial Ecology 27, 57-102.

Trull, T.W., Bray, S.G., Buesseler, K.O., Lamborg, C.H., Manganini, S., Moy, C., Valdes, J., 2008. In situ measurement of mesopelagic particle sinking rates and the control of carbon transfer to the ocean interior during the Vertical Flux in the Global Ocean (VERTIGO) voyages in the North Pacific. Deep-Sea Research II 55 1684-1695.

Trull, T.W., Sedwick, P.N., Griffiths, B.F., Rintoul, S.S., 2001a. Introduction to special section: SAZ project. Journal of Geophysical Research 106 (C12), 31/425-429. doi:10.1029/2001JC001008

Trull, T.W., Bray, S.G., Manganini, S.J., Honjo, S., Francois, R., 2001b. Moored sediment trap measurements of carbon export in the Subantarctic and Polar Frontal Zones of the Southern Ocean, south of Australia. Journal of Geophysica Research 106 (C12), 31/489-509. doi:10.1029/2000JC000308.

Volk, T., Hoffert, M.I., 1985. Ocean carbon pumps: analysis of relative strengths and efficiencies in ocean-driven atmospheric $\mathrm{CO}_{2}$ changes. Geophysical Monographs 32, 99-110.

Waite, A.M., Gustafsson, Ö., Lindahl, O., Tiselius, P., 2005. Linking ecosystem dynamics and biogeochemistry: sinking fractionation of organic carbon in a Swedish fjord. Limnology and Oceanography 50, 658-671.

Waite, A.M., Nodder, S.D., 2001. The effect of in situ iron addition on the sinking rates and export flux of Southern Ocean diatoms. Deep-Sea Research II 48 , 2635-2654

Wang, X., Matear, R., Trull, T.W., 2003. Nutrient utilization ratios in the Polar Frontal Zone in the Australian sector of the Southern Ocean: a model. Globa Biogeochemical Cycles 17, 1009. doi:10.1029/2002GB001938.

Wassmann, P., 1990. Relationship between primary and export production in the boreal coastal zone of the North Atlantic. Limnology and Oceanography 35, 464-471.

Wassmann, P., Carroll, J., Bellerby, R.G.J., 2008. Carbon flux and ecosystem feedback in the northern Barents Sea in an area of climate change: an introduction. Deep-Sea Research II 55, 2143-2153.

Westwood, K.J., Griffiths, F.B., Webb, J., 2011. Primary production in the SubAntarctic and Polar Frontal zones south of Tasmania, Australia; SAZ-Sense survey, 2007. Deep-Sea Research II 58, 2162-2178.

Wexels Riser, C., Wassmann, P., Reigstad, M., Seuthe, L., 2008. Vertical flux regulation by zooplankton in the northern Barents Sea during Arctic spring. Deep-Sea Research II 55, 2320-2329.

Wilson, S.E., Steinberg, D.K., Buesseler, K.O., 2008. Changes in fecal pellet characteristics with depth as indicators of zooplankton repackaging of particles in the mesopelagic zone of the subtropical and subarctic North Pacific Ocean. Deep-Sea Research II 55, 1636-1647. 